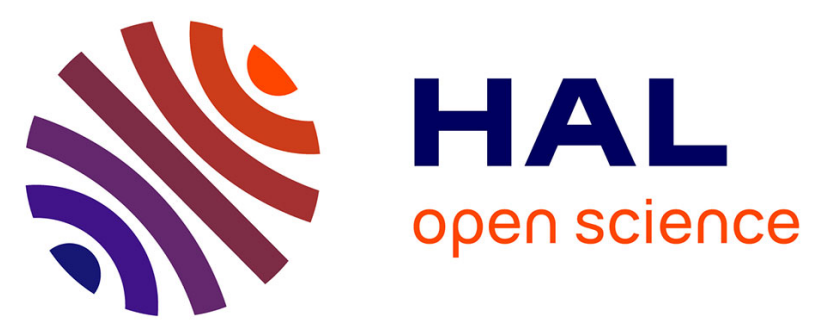

\title{
Fluid circulation in a complex volcano-tectonic setting, inferred from self-potential and soil CO2 flux surveys: The Santa María-Cerro Quemado-Zunil volcanoes and Xela caldera (Northwestern Guatemala)
}

Laura Bennati, Anthony Finizola, James A. Walker, Dina L. Lopez, I. Camilo Higuera-Diaz, Claudia Schütze, Francisco Barahona, Rafael Cartagena, Vladimir Conde, Renan Funes, et al.

\section{- To cite this version:}

Laura Bennati, Anthony Finizola, James A. Walker, Dina L. Lopez, I. Camilo Higuera-Diaz, et al.. Fluid circulation in a complex volcano-tectonic setting, inferred from self-potential and soil CO2 flux surveys: The Santa María-Cerro Quemado-Zunil volcanoes and Xela caldera (Northwestern Guatemala). Journal of Volcanology and Geothermal Research, 2011, 199 (3-4), pp.216-229. 10.1016/j.jvolgeores.2010.11.008 . hal-01148210

\author{
HAL Id: hal-01148210 \\ https://hal.science/hal-01148210
}

Submitted on 3 Nov 2016

HAL is a multi-disciplinary open access archive for the deposit and dissemination of scientific research documents, whether they are published or not. The documents may come from teaching and research institutions in France or abroad, or from public or private research centers.
L'archive ouverte pluridisciplinaire HAL, est destinée au dépôt et à la diffusion de documents scientifiques de niveau recherche, publiés ou non, émanant des établissements d'enseignement et de recherche français ou étrangers, des laboratoires publics ou privés. 


\title{
Fluid circulation in a complex volcano-tectonic setting, inferred from self- potential and soil $\mathrm{CO}_{2}$ flux surveys: The Santa María-Cerro Quemado-Zunil volcanoes and Xela caldera (Northwestern Guatemala)
}

\author{
Laura Bennati $^{\mathrm{a}, *}$, Anthony Finizola ${ }^{\mathrm{b}}$, James A. Walker ${ }^{c}$, Dina L. Lopez ${ }^{\mathrm{d}}$, I. Camilo Higuera-Diaz ${ }^{\mathrm{c}}$, \\ Claudia Schütze ${ }^{e}$, Francisco Barahona ${ }^{f}$, Rafael Cartagena ${ }^{f}$, Vladimir Conde ${ }^{f}$, Renan Funes ${ }^{f}$, Cristobal Rios ${ }^{f}$ \\ ${ }^{\mathrm{a}}$ Earth and Atmospheric Sciences Department, Purdue University, West Lafayette, IN, USA \\ b Laboratoire GéoSciences Réunion, Université de la Réunion, IPGP, UMR 7154, Saint Denis, La Réunion, France \\ c Department of Geology and Environmental Geosciences, Northern Illinois University, DeKalb, IL, USA \\ d Department of Geological Sciences, Ohio University, Athens, OH, USA \\ e UFZ, Helmholtz Centre for Environmental Research, Department of Monitoring and Exploration Technologies, Leipzig, Germany \\ f Instituto de Ciencias de la Tierra, Universidad de El Salvador, San Salvador, El Salvador
}

\author{
A B S T R A C T
}

\begin{abstract}
The region encompassing Santa María, Cerro Quemado, and Zunil volcanoes, close to Quetzaltenango, the second largest city of Guatemala, is volcanically and tectonically complex. In addition, the huge Xela caldera, about $20 \mathrm{~km}$ in diameter, crosses this area and links up to the important Zunil fault zone located between the three volcanoes. Two highly active geothermal sites, named Zunil-I and Zunil-II, are also located between these three volcanic edifices at the southeastern boundary of Xela caldera. In order to determine the permeability variations and the main structural discontinuities within this complex volcano-tectonic setting, self-potential and soil $\mathrm{CO}_{2}$ flux measurements have been coupled, with a step of $20 \mathrm{~m}$, along a $16.880 \mathrm{~km}$-long profile crossing the entire area. Two shallow hydrothermal systems, with maximum lateral extensions of $1.5 \mathrm{~km}$ in diameter, are indicated by positive self-potential/elevation gradients below Santa María and Cerro Quemado volcanoes. Such small hydrothermal systems cannot explain the intense geothermal manifestations at Zunil-I and Zunil-II. Another minor hydrothermal system is indicated by self-potential measurements on the flank of Santa María along the edge of the Xela caldera. $\mathrm{CO}_{2}$ flux measurements display slight variations inside the caldera and decreasing values crossing outside the caldera boundary. We hypothesize the presence of a magmatic body, inside the southeastern border of Xela caldera, to explain the deeper and more intense hydrothermal system manifested by the Zunil-I and the Zunil-II geothermal fields. This magmatic system may be independent from Santa María and Cerro Quemado volcanoes. Alternatively, the hypothesized Xela magmatic system could have a common magmatic origin with the Cerro Quemado dome complex, consistent with previous findings on regional gas emissions. Sectors bordering the Cerro Quemado dome complex also have high amplitude minima-short wavelength anomalies in self-potential, interpreted as preferential rain water infiltration along faults of major permeability, probably related with the most recent stages of Cerro Quemado dome growth.
\end{abstract}

\section{Introduction}

Presence of water is one of the main parameters controlling terrestrial volcanic activity. Inside active volcanoes, water is the mobile phase responsible for transferring energy and mass, from depth toward the surface, generating hydrothermal systems. It can also be confined into aquifers. Usually hydrothermal systems within volcanoes form compartments that are just above a percolation

\footnotetext{
* Corresponding author. Earth and Atmospheric Sciences Department, Purdue University, 550 Stadium Mall Drive, West Lafayette, IN 47907-2051, USA. Tel.: + 1 765494 6787; fax: +1 7654961210 .

E-mail address: lbennati@purdue.edu (L. Bennati).
}

threshold because of the interplay between flow, dissolution/ precipitation and fracturing related to stress and strain variations. Visible manifestations of hydrothermal fluid flow are fumaroles and thermal waters/springs. Sometimes, quiet hydrothermal fluid flow is disrupted by interaction with rising magma, triggering explosive phreatomagmatic activity. Between eruptive periods, hydrothermal activity creates zones of weakness inside volcanoes by hydrothermal alteration of volcanic rocks. These areas increase the risk of potential failure on edifice flanks (Lopez and Williams, 1993; Frank, 1995; Van Wyk de Vries et al., 2000; Reid et al., 2001; Reid, 2004; Aizawa, 2008). Therefore, studying fluid flow inside active volcanoes is important for complete volcanic hazard assessments. Moreover, the study of hydrothermal systems and their components is also the first step in 
discovering new sites for potential geothermal energy exploitation, or improving the knowledge and development plans of sites under exploitation (Nieva et al., 1997; Mahar et al., 2003; Negraru et al., 2008).

This study aims to identify the main axis of fluid flow and the hydrothermal systems extension across an active volcanic area. Our region of interest is located close to Quetzaltenango, the second largest city of Guatemala ( 300,000 inhabitants), in Central America (Fig. 1A and B). This region contains six volcanoes: Santa María, Santiaguito, Cerro Quemado, Zunil, Santo Tomàs, and Siete Orejas, in a $300 \mathrm{~km}^{2}$ area (Fig. 1C). Our fieldwork has been concentrated on the Santa María, Cerro Quemado, and Zunil volcanoes. We selected these
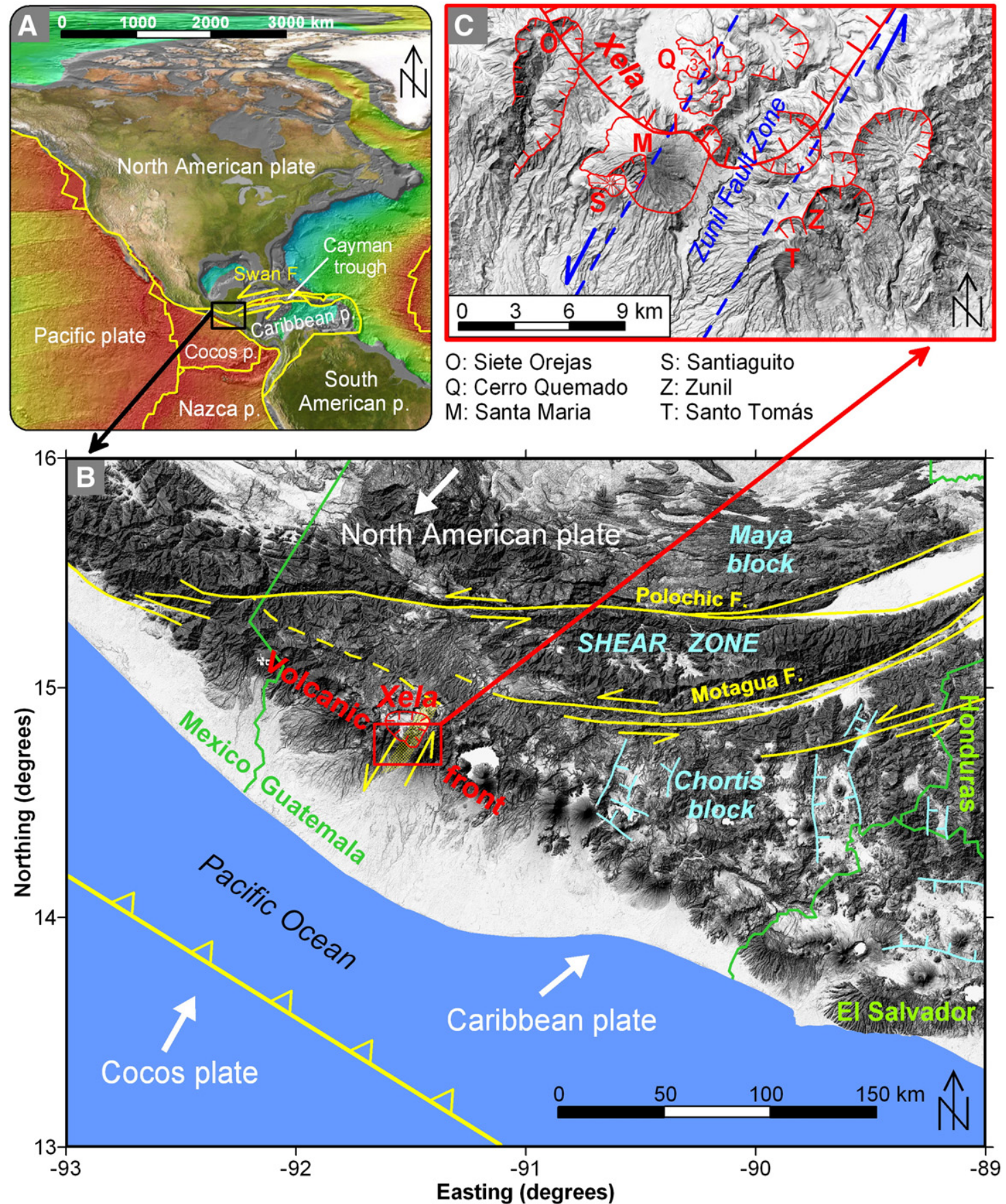

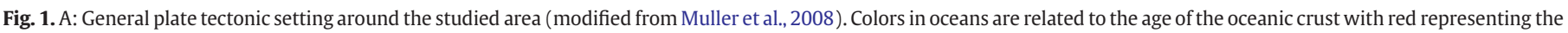

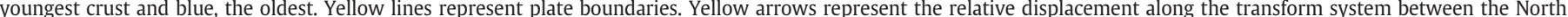

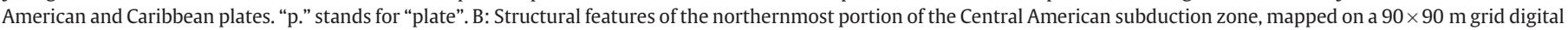

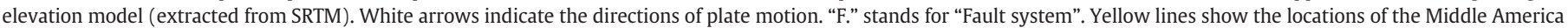

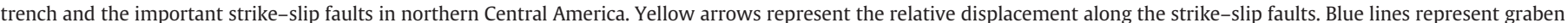

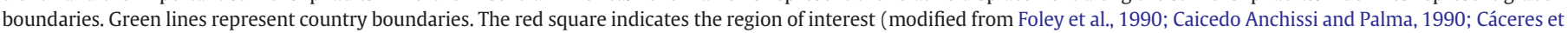

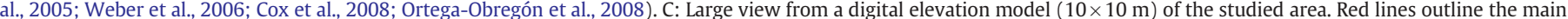

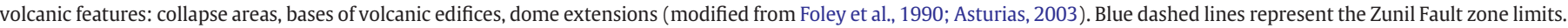

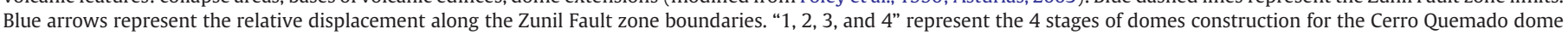
complex (modified from Conway et al., 1992). (For interpretation of the references to colour in this figure legend, the reader is referred to the web version of this article.) 
three edifices because (1) of the Plinian eruption of Santa María in 1902 of VEI 6 (Fig. 2A), (2) the recent lava dome extrusion of Cerro Quemado in 1818 (Fig. 2B), and (3) the present-day strong hydrothermal manifestations concentrated between Cerro Quemado and Zunil volcanoes, in two regions named Zunil-I and Zunil-II (Fig. 2C).

Fluid flow is channelized along zones of higher permeability; therefore identifying zones of fluid flow is valuable in highlighting the main weakness planes crossing a volcanic edifice (Lénat, 1987; Lénat et al., 1998; Finizola et al., 2002, 2003; Lewicki et al., 2003; Revil et al.,
2004; Finizola et al., 2004, 2009). Sometimes, these fault zones can be sealed (Revil and Cathles, 2002a,b; Ball et al., 2010). When these faults are more permeable, the fluid flow information is of first importance in volcanic hazard assessments as vent initiation and flank failure are often centered on areas of preexisting weakness. These weak regions can be old volcanic structural boundaries or tectonic faults. In order to study fluid flow, the following geophysical and geochemical methods have been coupled: (1) self-potential technique, sensitive to water flow associated with hydrogeological and hydrothermal systems and (2) soil diffuse degassing technique, sensitive to $\mathrm{CO}_{2}$ ascent, generally
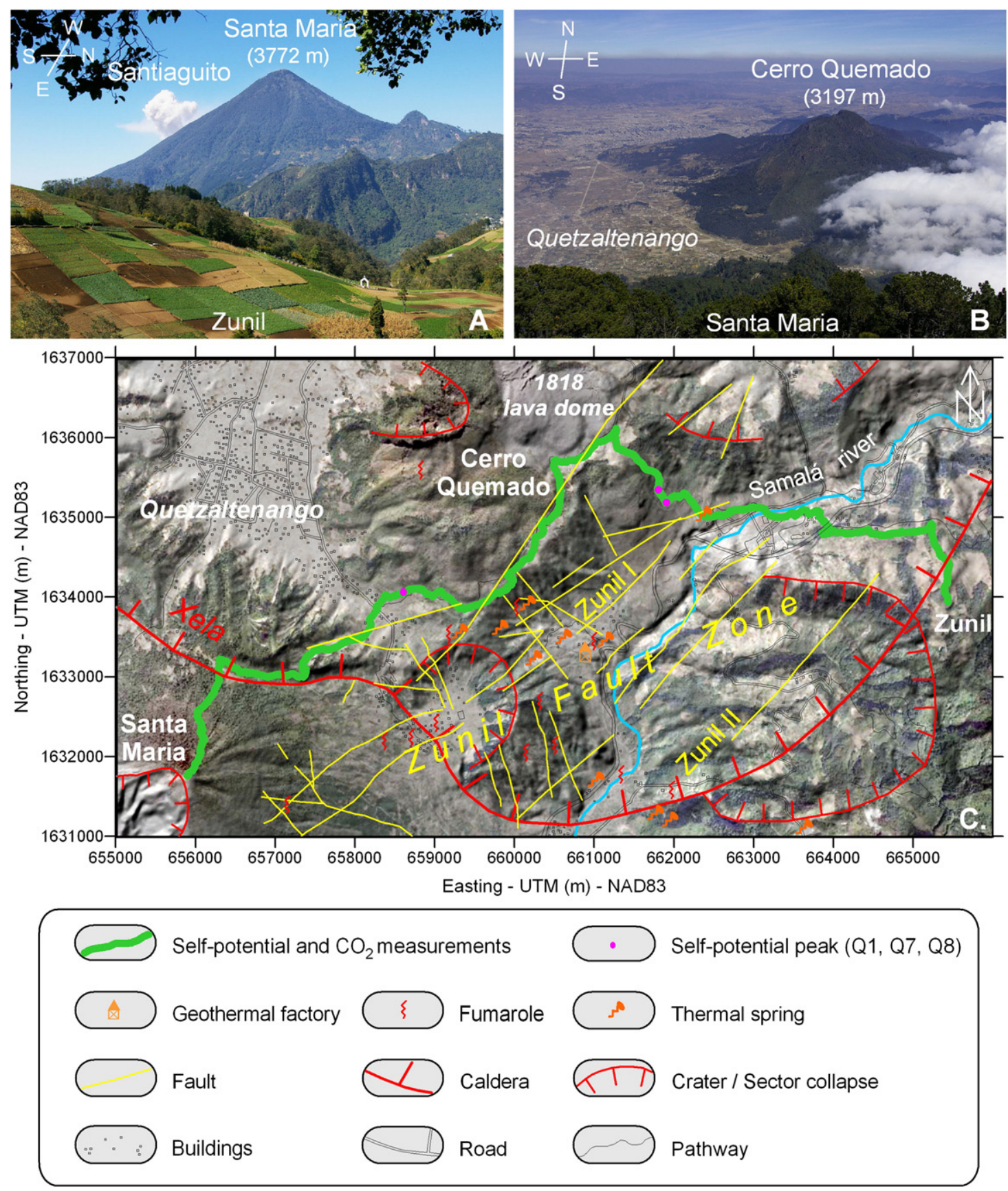

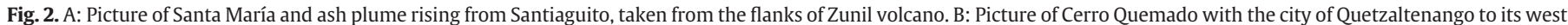

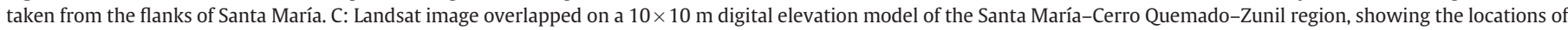

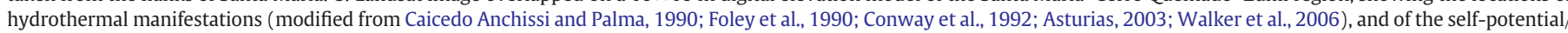
soil $\mathrm{CO}_{2}$ traverse. Self-potential peaks (Q1, Q7, and Q8) are discussed in the text. 
of a deep magmatic origin. Coupling these two techniques furnishes information about possible links between the shallower hydrothermal system and the deeper magmatic system.

\section{Tectonic setting and historical volcanic activity}

\subsection{Tectonic setting}

Guatemala, located in northern Central America, sits in a complex tectonic setting where crustal deformation results from interactions between the North American, the Cocos, and the northwestern corner of the Caribbean plates (Fig. 1A and B). Movements between the North American and Caribbean plates take place along several hundreds of kilometers of curvilinear left-lateral strike slip faults called the Swan, Motagua, and Polochic transform faults (Fig. 1A and B) (Cáceres et al., 2005; Cox et al., 2008; Ortega-Obregón et al., 2008). The Swan transform fault (Fig. 1A) connects the southern end of the Cayman trough with the Guatemalan Motagua fault (Fig. 1B) (Rosencrantz and Mann, 1991). The North American-Caribbean (NAC) plate boundary is seismically well defined. Historical earthquakes of note include: the series of earthquakes in 1816 on the Polochic fault (M7.5 to 7.75) (White, 1985), the 1856 earthquake on the Swan fault (M7 to 8), and the 1976 Motagua fault earthquake (M7.5), which produced about $2 \mathrm{~m}$ of slip motion (Kanamori and Stewart, 1978). Slip rate along this plate boundary ranges between 11 and $25 \mathrm{~mm} /$ year (DeMelts et al., 2000). Along the Pacific coast, the Cocos plate is subducting beneath the Caribbean plate in a northeast direction. Its slip rate through Central America ranges from 60 to $85 \mathrm{~mm} /$ year, with higher values toward the south (DeMelts, 2001). Numerous earthquakes have also been recorded along the subduction zone with magnitudes reaching up to 8 (White and Harlow, 1993). Cocos subduction has generated the Central American volcanic front, which runs less than $100 \mathrm{~km}$ from the coast (Fig. 1B). Several segments have been identified in this volcanic front, from Guatemala to Costa Rica, defined by varying geological, tectonical or volcanological parameters, such as the strike of volcanic lineaments (Stoiber and Carr, 1973; Carr et al., 1982; Carr, 1984). Despite the significance of the Cocos-Caribbean plate boundary for present-day volcanism, recent tectonic surveys suggest that a large fraction of the intraplate deformation in northern Central America is due to interaction along the NAC plate boundary (Cáceres et al., 2005). Late Cretaceous transpressional tectonism has been recorded along the Motagua fault as high pressure-low temperature metamorphism (Brueckner et al., 2009). The NAC plate boundary consists of a complex system of large-scale faults that separate blocks with compressional geologic features (Donnelly et al., 1990; Giunta et al., 2002; Rogers, 2003; Ortega-Gutiérrez et al., 2007; Phipps Morgan et al., 2008). The Maya block (Fig. 1A and B) of southeastern Mexico, Belize, and Guatemala is the southernmost continental assemblage of the North American plate, whereas the Chortís block in Guatemala, Honduras, and the Nicaragua rise is the northernmost part of the Caribbean plate (McBirney, 1963; Weyl, 1980; Donnelly et al., 1990; Ortega-Gutiérrez et al., 1995; Keppie, 2004). The collision between the Chortís and Maya blocks, responsible for ophiolite obduction, occurred between 74 and $65 \mathrm{Ma}$ (Ortega-Obregón et al., 2008). Estimates of Cenozoic displacements along the Motagua fault system are of about $170 \mathrm{~km}$ (Donnelly et al., 1990). The present-day area located between the Polochic and Motagua faults constitutes an important shear zone (Ortega-Obregón et al., 2008). Near to the western end of the Motagua fault, detailed geological studies have defined a major regional fault zone, with an approximate NE-SW direction, more or less perpendicular to the Motagua fault axis, named the Zunil fault zone (Fig. 1B and C) (Newhall, 1987; Foley et al., 1990; Asturias, 2003). Faulting in this area has been linked to the segmentation of the volcanic front proposed by Stoiber and Carr (1973). Although the relationship between the Zunil fault zone and the end of Motagua fault is not well established, faulting seems to be compatible with strain accommodation between the Maya and Chortis blocks motion (Phipps Morgan et al., 2008). The Zunil fault zone is also located on the eastern border of a huge $\sim 15 \times 20 \mathrm{~km}$ caldera; the Xela (or Quetzaltenango) caldera (Fig. 1B and C) (Foley et al., 1990; Duffield et al., 1993; Asturias, 2003). The age of the caldera is still a subject of investigation and is currently comprised between $84 \mathrm{ka}$ and $12 \mathrm{Ma}$ (Duffield et al., 1993). The linear shape of the eastern border of Xela caldera clearly suggests tectonic control by the Zunil fault zone.

Our study area is located inside this complex tectonic setting. It includes the Zunil fault zone, and the southern border of the Xela caldera, and contains seven volcanoes, three of which being active during historical times (Santiaguito, Santa María, and Cerro Quemado).

\subsection{Volcanic and hydrothermal activity}

Our area of interest (Figs. 1C and 2) lies on a surface of Quaternary and Tertiary volcanic rocks underlain by older igneous and metamorphic rocks (Williams, 1960; Rose, 1987a,b; Adams et al., 1990; Foley et al., 1990). Our study area contains three historically active volcanoes: Santiaguito, Santa María, and Cerro Quemado, three inactive volcanoes, and one well-documented hydrothermal area.

Santa María stratovolcano (Figs. 1C, 2A, and C) has had three discrete eruptive stages: (1) stratovolcano construction, (2) Plinian eruption, and (3) dome growth (Rose et al., 1977a; Conway et al., 1994; Escobar-Wolf et al., 2010). Using paleomagnetic and ${ }^{40} \mathrm{Ar} /{ }^{39} \mathrm{Ar}$ data, Escobar-Wolf et al. (2010) show that the first stage lasted from $103 \mathrm{ka}$ to $35 \mathrm{ka}$, producing a modest cone $\left(\sim 8 \mathrm{~km}^{3}\right)$. After a long period without any activity, about $5-10 \mathrm{~km}^{3}$ (DRE) of dacitic magma dramatically erupted in October 1902 (Rose, 1972a; Williams and Self, 1983). This eruption was one of the largest of the 20th century, killing about 5000 people (Rose, 1972a; Conway et al., 1994) and creating a huge crater/amphitheatre on the southwestern flank of the Santa María edifice. In 1922, after 20 years of quiescence, dacitic lava started to extrude in the 1902 crater (Stoiber and Rose, 1969; Rose, 1973, 1987a; Harris et al., 2002, 2004), forming the large $\left(\sim 1 \mathrm{~km}^{3}\right)$, intricate Santiaguito dome, which remains active today (Stoiber and Rose, 1969; Rose, 1972b, 1973, 1987a; Anderson et al., 1995; Barmin et al., 2002; Harris et al., 2002, 2003, 2004). Dome construction has been characterized by alternating periods of rapid enlargement during intense extrusion periods lasting 3 to 6 years, and longer periods of reduced growth rates (Rose, 1987a; Harris et al., 2003). Dome growth at Santiaguito has been occasionally accompanied by other styles of eruptive activity, including pyroclastics flows, vertical pyroclastics eruptions, and lahars (Rose, 1973, 1974; Rose et al., 1977b; Rose, 1987a). Minor vertical ash explosions are a daily occurrence and are thought to be phreatomagmatic, resulting from infiltrated meteoric water, which is vaporized by the heat of the hot erupted rocks from a deep magma body (Sanchez Bennett et al., 1992). Important hydrothermal manifestations have been observed on Santa María, most notably the numerous fumaroles seen on and by the Santiaguito dome since its birth in 1922 (Stoiber and Rose, 1969, 1970, 1974). In addition, Walker et al. (2006) highlighted the presence of thermal springs on the south-southwestern flank of Santa María.

Cerro Quemado, an exogenous dome complex, is located $10 \mathrm{~km}$ northeast of Santa María volcano (Figs. 1C, 2B, and C). It is the largest and most recent of a series of domes bordering the southern part of Quetzaltenango city (Williams, 1960; Conway et al., 1992). The volcanic activity at Cerro Quemado has been subdivided by Conway et al. (1992) into four stages. The southern and northern parts of the volcano were formed by andesitic and dacitic lava flows, and domes (phases 1 and 2 on Fig. 1C). The third phase started in 1020 yr B.P. and was characterized by a large explosion with debris avalanches, a laterally directed pyroclastic blast, and pyroclastics flows (phase 3 on Fig. 1C). The explosion left a horseshoe-shaped scar on the western flank of the volcano (Fig. 2C). Conway et al. (1992) showed that the blocky lava flows erupted in 1818 define the fourth and last stage of Cerro Quemado construction (phase 4 on Fig. 1C). The present activity of Cerro Quemado consists solely of hydrothermal manifestations, 
including fumaroles at about $500 \mathrm{~m}$ elevation, to the south of the horseshoe-shaped scar (Fig. 2C).

Zunil volcano is a deeply dissected edifice, located east of Santa María, and lying close to Santo Tomás volcano (Fig. 1C) (Williams, 1960). Neither volcano has shown any historical activity (Rose, 1987b).

Siete Orejas, the last volcano located in the studied area, is a stratovolcano, which experienced a large Plinian eruption $\left(>2 \mathrm{~km}^{3}\right.$ of magma ejected) ca. 120-150 ka (Williams, 1960; Rose et al., 1999). The volcano is now deeply dissected and has a wide south-opening caldera (Williams, 1960; Duffield et al., 1993).

Snaking between Santa María, Cerro Quemado, and Zunil volcanoes is the Samalá River, which is surrounded on both sides by numerous regional faults that form the Zunil fault zone. This later lies parallel and close to the eastern border of Xela caldera (Foley et al., 1990; Duffield et al., 1993). The principal direction of this fault system is NE-SW. A secondary fault system is primarily oriented NNW-SSE (Fig. 2C). Two regions of intense hydrothermal activity (characterized by fumaroles and thermal springs) are associated with these two faults systems, covering an area of about $4 \mathrm{~km}$ in diameter. The first zone, called Zunil$\mathrm{I}$, is located on the western side of the Samalá River and a few kilometers SE of Cerro Quemado (Templeton, 1999). Within Zunil-I, a geothermal power plant is producing $24 \mathrm{MW}$, supplying electricity for Quetzaltenango city. The second hydrothermal area is called Zunil-II, or Sulfur Mountain. It is located on the eastern side of the Samalá River and on the western flank of Zunil volcano, and it is surrounded by a semicircular caldera, $3 \mathrm{~km}$ in diameter (Figs. 1C and 2C) (Adams et al., 1990; Foley et al., 1990; Giggenbach et al., 1992; Duffield et al., 1993; Lima Lobato and Palma, 2000; Asturias, 2003). A big debate is still going on about the exact location of the thermal/magmatic body responsible for these two intense geothermal zones. It was first suggested to be beneath Zunil volcano (Giggenbach et al., 1992). Barmin et al. (2002), on the other hand, suggested that it could be an extensive hydrothermal system, centered right below the 1902 Santa María crater and Santiaguito dome. Finally, using spring water isotopic geochemistry, Walker et al. (2006) stated that the source responsible for Zunil-I and Zunil-II hydrothermal activity could be linked to the Cerro Quemado edifice, the nearest historically active volcano. Based on the new results obtained from our survey, we will discuss these three hypotheses in the following sections.

\section{Methods}

As described in the Introduction, self-potential and soil $\mathrm{CO}_{2}$ diffuse degassing techniques have been used in this survey. The aim of coupling these techniques is to identify the higher permeability structures for fluid movement within this very complex volcanic region.

\subsection{Self-potential}

Self-potential measurements were carried out with a pair of nonpolarisable $\mathrm{Cu} / \mathrm{CuSO}_{4}$ electrodes. This method consists in measuring, directly at the ground surface, the natural difference of electrical potential between two points. This potential difference is measured between the reference electrode and a moving electrode with a high impedance voltmeter (sensitivity of $0.1 \mathrm{mV}$, internal impedance of $100 \mathrm{MOhm}$ ), and an isolated copper cable, $300 \mathrm{~m}$-long. At each station, a $\sim 15 \mathrm{~cm}$ deep hole was dug to improve the electrical contact between the electrode and the ground. The offset error between the two electrodes was always less than $1 \mathrm{mV}$. To avoid increasing this offset along the entire profile, we switched moving and reference electrodes for the next set of measurements.

On active volcanoes, the main source of a self-potential signal is electrokinetic coupling (Corwin and Hoover, 1979; Zlotnicki and Nishida, 2003; Ishido, 2004). In short, the flow of ground water creates a macroscopic current density and an electrical field, called the streaming potential, measurable at the ground surface (Lorne et al., 1999a,b; Revil et al., 1999a,b; Revil and Leroy, 2001). Positive selfpotential anomalies associated with thermal anomalies are well explained by the electrokinetic theory. The zeta potential, a key parameter describing electrokinetic effects, is generally negative. This means that the interface between the rock (or mineral) and the fluid is negatively charged. This charge is counterbalanced by positive mobile charges in more external layers. Fluid flowing in the pore space (e.g. hydrothermal convecting water) carries these mobile charges downstream, thus making the downstream region positively charged (Overbeek, 1952; MacInnes, 1961; Revil, 2002). As a consequence, the electrokinetic effect associated with the uprising of steam/liquid water in volcanic hydrothermal systems will generally result in positive anomalies (positive charges moving in the flow direction), and the downward movement of fluids in negative anomalies (Pribnow et al., 2003; Zlotnicki and Nishida, 2003; Finizola et al., 2004; Revil et al., 2004, 2008; Barde-Cabusson et al., 2009a,b; Finizola et al., 2009). Self-potential surveys on active volcanoes have found anomalies of a few hundreds to thousands of $\mathrm{mV}$ in amplitude, corresponding to active hydrothermal systems and preferential rainwater infiltration. Positive anomalies are generally centered on summit crater areas (Lénat et al., 1998; Finizola et al., 2003, 2004, 2006; Aizawa et al., 2008), on volcano flanks, or above lateral vents, eruptive fissures, and magmatic intrusions (Zablocki, 1976; Aubert and Kieffer, 1984; Jackson and Kauahikaua, 1987; Lénat, 1987; Malengreau et al., 1994; Lewicki et al., 2003). The location of the centered self-potential anomaly at summit crater areas is consistent with convective circulation cells driven by the heat released by magmatic chambers, as suggested by computer modeling results (Todesco, 1997), physicochemical models of volcanic systems (Henley and Ellis, 1983; Giggenbach et al., 1990), and three dimensional resistivity distribution (Onizawa et al., 2009).

\subsection{Soil $\mathrm{CO}_{2}$ flux}

$\mathrm{CO}_{2}$ fluxes were acquired using the "accumulation chamber method", a passive geochemical technique for measuring $\mathrm{CO}_{2}$ diffuse degassing from soils (Chiodini et al., 1998). $\mathrm{CO}_{2}$ soil diffuse degassing measurements were carried out by means of a portable diffuse flux meter developed by WestSystems corporation and equipped with an IR spectrometer (LICOR $820 \mathrm{CO}_{2}$ analyzer), an accumulation chamber Type A (internal volume: $0.003 \mathrm{~m}^{3}$ ), and a Pocket PC to visualize the data. The gas-air mixture within the accumulation chamber is continuously analyzed by the IR spectrometer while concentration/ time curves are plotted on the PC. The accumulation chamber is placed on top of the soil and gases emitted by the soil accumulate within the chamber. The method is based on the measurement of the $\mathrm{CO}_{2}$ concentration increasing inside the accumulation chamber; the slope of the curve $\left(\mathrm{CO}_{2}\right.$ concentration versus time) is directly proportional to the flux. In addition to natural organic sources, the $\mathrm{CO}_{2}$ emitted by soils in volcanic areas can have volcanic origin. High $\mathrm{CO}_{2}$ anomalies mainly have their origin in magma degassing inside volcanic systems. Magmatic gases follow the same high permeability pathways as hydrothermal fluids, providing information about zones where there is both vertical permeability and the presence of a source gas release at depth. $\mathrm{CO}_{2}$ flux surveys performed on active volcanoes and/or tectonic active areas have highlighted huge anomalies associated with active vents, old crater boundaries, and tectonic faults (Allard et al., 1991; Chiodini et al., 1996; Etiope et al., 1999; Lewicki et al., 2003; Revil et al., 2008).

\section{Data acquisition and results}

Self-potential and $\mathrm{CO}_{2}$ flux measurements were performed in January 2007 along a unique profile crossing several active volcanoes: Santa María, Cerro Quemado, and Zunil edifices, and also hypothesized 
structural discontinuities (Figs. 1C and 2C). The direction of the profile is west-east, and its length is $16.880 \mathrm{~km}$. 848 collocated data points were measured along the profile, every $20 \mathrm{~m}$, for both self-potential and $\mathrm{CO}_{2}$ flux. Data positions were recorded on a handheld GPS receiver and corresponding elevations have been extracted from a precise $(10 \times 10 \mathrm{~m})$ digital elevation model.

\subsection{Raw self-potential and $\mathrm{CO}_{2}$ flux signals}

The west-east profile is shown in Fig. 3, where topography (brown), self-potential (blue), and soil $\mathrm{CO}_{2}$ flux (red) have been plotted versus distance. The self-potential signal displays large variations (close to $1000 \mathrm{mV}$ ). Based on the topography and selfpotential signal variations, we have subdivided the profile into four major segments: (1) Santa María (M), (2) Cerro Quemado (Q), (3)
Samalá River (S), and (4) Zunil (Z). For each segment, based on the self-potential/elevation relationships, further subdivisions have been made.

The first major segment, $M$, is located on the eastern flank of Santa María volcano. In this segment, the self-potential signal displays a general "V" shape (M1 through M6 subsections). This "V" shape is slightly disrupted by the M4 sector. The self-potential signal remains nearly flat on subsection $\mathrm{M} 7$.

The second segment, $\mathrm{Q}$ corresponds to the Cerro Quemado dome. It displays a fluctuating self-potential signal (from Q2 to Q6) bordered by sharp self-potential negative peaks on both sides. The negative peak on the western side of the dome, Q1, has an amplitude of about $450 \mathrm{mV}$, while the two negative anomalies, $\mathrm{Q} 7$ and Q8, on the eastern side of the dome, have lower amplitudes (about $200 \mathrm{mV}$ for Q7 and $120 \mathrm{mV}$ for Q8).

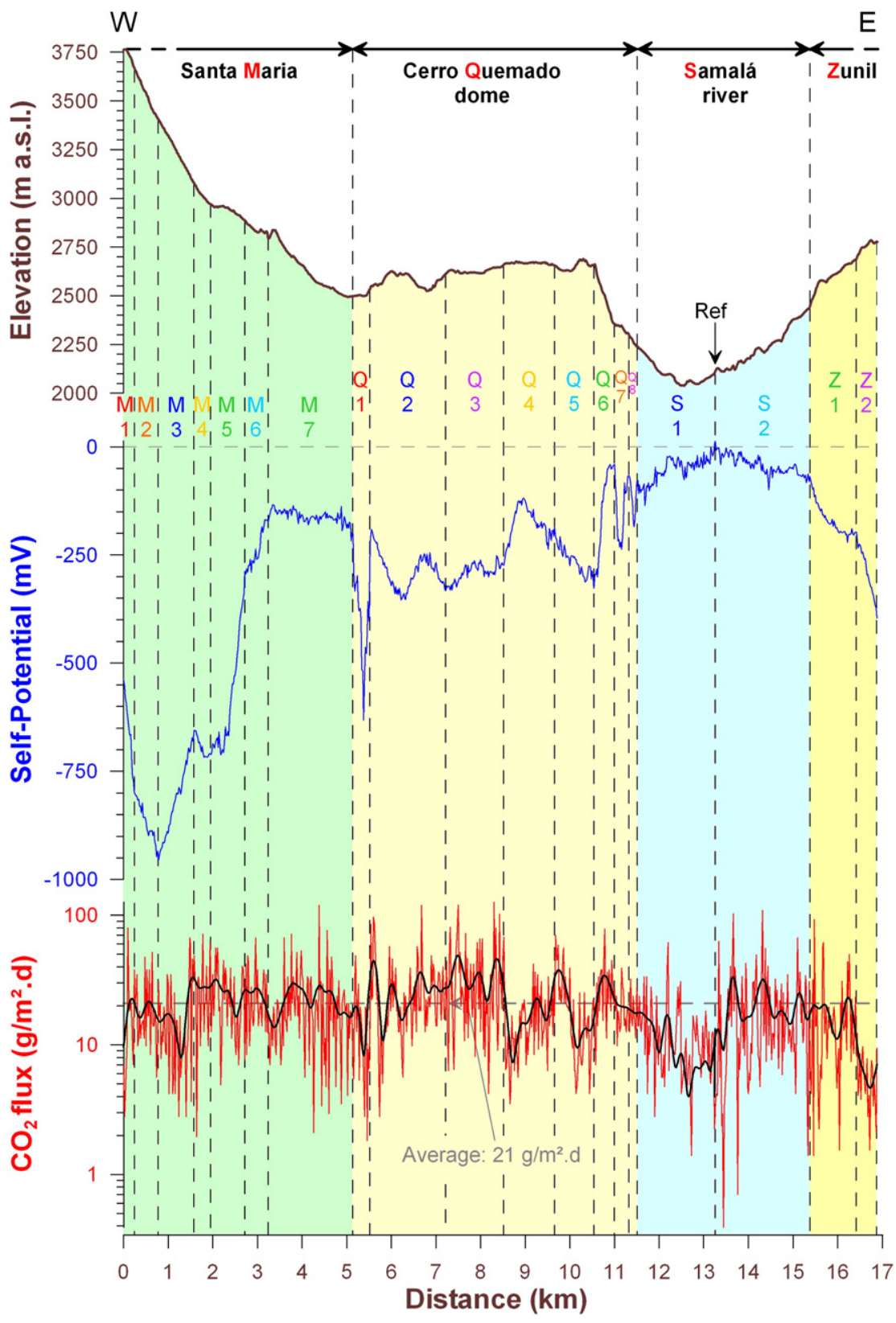

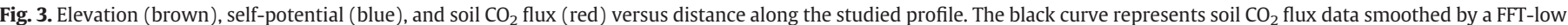

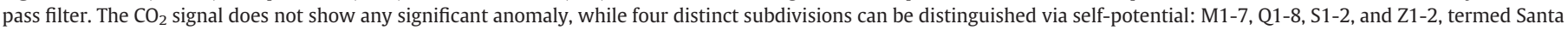

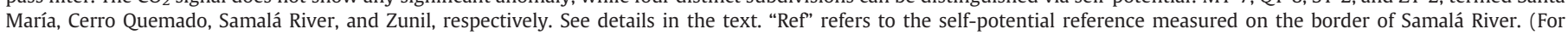
interpretation of the references to colour in this figure legend, the reader is referred to the web version of this article.) 

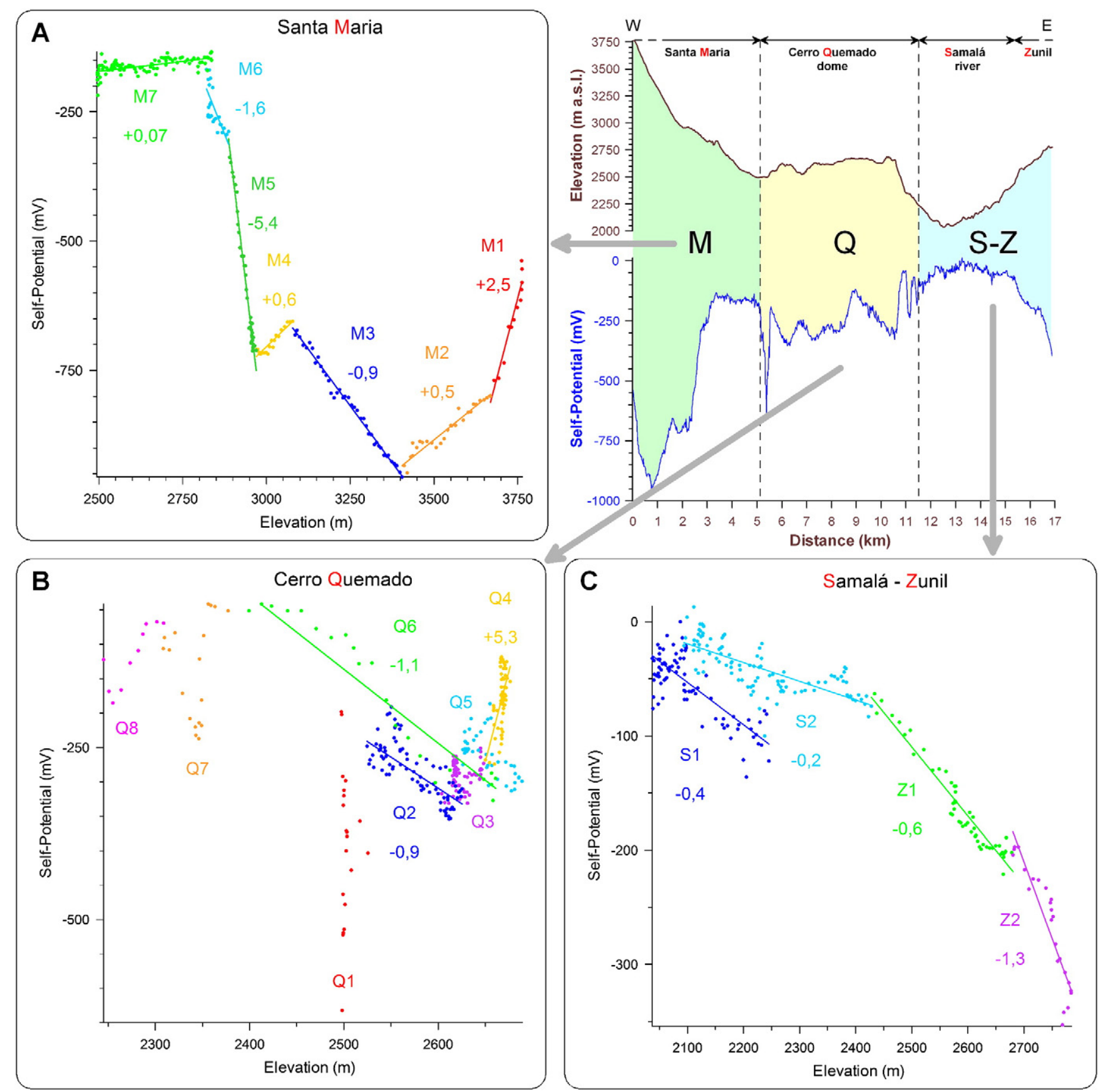

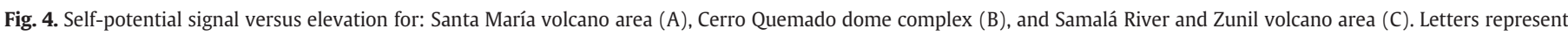

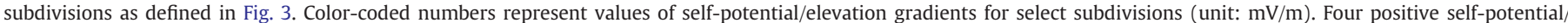

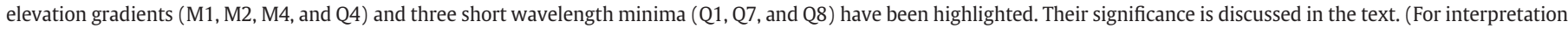
of the references to colour in this figure legend, the reader is referred to the web version of this article.)

The third (S) and fourth (Z) segments, corresponding respectively to the Samalá River and Zunil volcano, are characterized by a selfpotential signal, which exhibits an excellent negative correlation with the surface topography. The boundary between the third and fourth segments has been defined by a sharp break in the slope of the selfpotential signal.
$\mathrm{CO}_{2}$ flux data display a weak oscillation along the entire profile (Fig. 3). No significant peak can be distinguished. The average degassing value along the profile is of about $21 \mathrm{~g} / \mathrm{m}^{2} \mathrm{~d}$, and $\mathrm{CO}_{2}$ flux data range from not measurable to $125 \mathrm{~g} / \mathrm{m}^{2} \mathrm{~d}$. Such a value of soil $\mathrm{CO}_{2}$ flux is low in comparison to average values measured on active degassing volcanoes such as Miyakejima: $235 \mathrm{~g} / \mathrm{m}^{2} \mathrm{~d}$ (Hernández

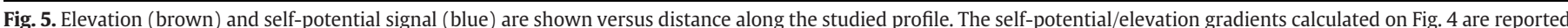

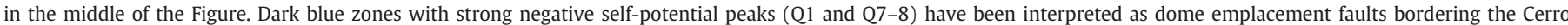

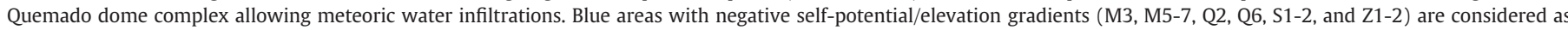

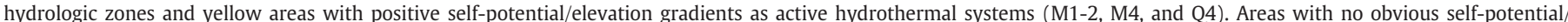

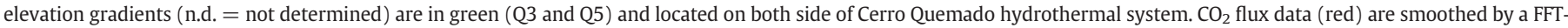

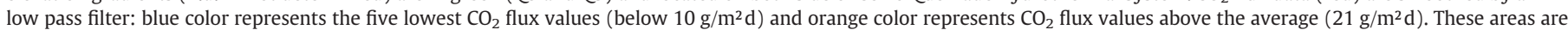
discussed in the text. (For interpretation of the references to colour in this figure legend, the reader is referred to the web version of this article.) 


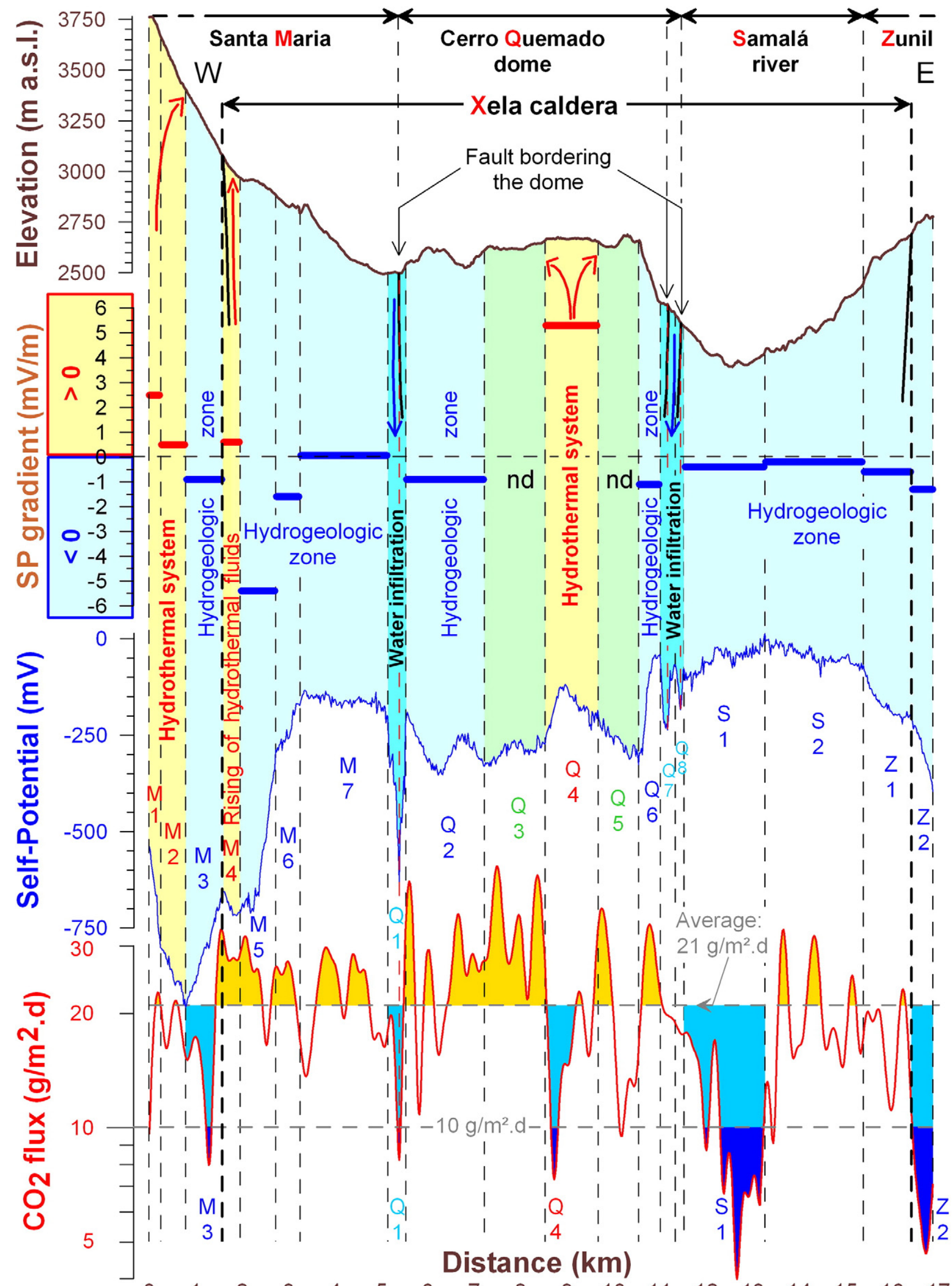

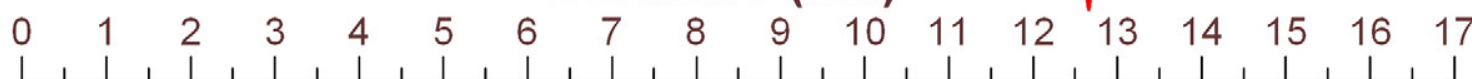


et al., 2001); Vulcano: between 129 and $2750 \mathrm{~g} / \mathrm{m}^{2} \mathrm{~d}$ (Granieri et al., 2006); summit of Teide: $717 \mathrm{~g} / \mathrm{m}^{2} \mathrm{~d}$ (Hernández et al., 1998); Mammoth Mountain: between 897 and $2414 \mathrm{~g} / \mathrm{m}^{2} \mathrm{~d}$ (Gerlach et al., 1998); Solfatara of Pozzuoli: $1478 \mathrm{~g} / \mathrm{m}^{2} \mathrm{~d}$ (Chiodini et al., 1998). Note that in the cited references, volcanic areas that present very high values of $\mathrm{CO}_{2}$ degassing correspond to actively convective zones (surficial manifestations such as fumaroles, etc.) rather than zones where soil gases are discharged quietly in a diffuse way. Similar low range of soil $\mathrm{CO}_{2}$ degassing values has been measured on Salvadorian volcanoes (e.g. San Miguel Volcano, Cartagena et al., 2004; San Salvador Volcano, Pérez et al., 2004; Ilopango Caldera, Lopez et al., 2004), and Popocatepetl Volcano in Mexico (Varley and Armienta, 2001). Nevertheless, the average flux is above the normal soil degassing rates (Scheffer and Schachtschabel, 1989). A FFT-low pass filter minimizes the influence of high-frequency noise and was applied to smooth the raw data (see black curve in Fig. 3). On this smoothed curve, a degassing minimum seems to coincide with the minimum in surface topography of the Samalá River valley. However, there is no evident correlation between self-potential and $\mathrm{CO}_{2}$ flux signals.

\subsection{Self-potential/elevation gradient analysis}

As described in the "3. Methods" chapter, the general trend of a self-potential signal crossing a volcanic edifice is enough to discriminate between hydrogeological and hydrothermal zones (Zlotnicki and Nishida, 2003; Finizola et al., 2004; Ishido, 2004).

A more detailed analysis of a self-potential signal versus elevation often identifies linear segments separated by sharp breaks in slope. As shown by previous studies performed on Misti volcano (Finizola et al., 2004; Tort and Finizola, 2005), these breaks in slope help distinguish the hydrogeologic transition between the ground surface and the water-saturated zone, and also the hydrothermal transition between the water evaporation level and the ground surface. A similar approach, studying self-potential/elevation gradients, has been applied on the entire west-east profile. For clarity, we have separated the self-potential/elevation plots into 3 parts: Santa María, Cerro Quemado and Samalá-Zunil (Fig. 4).

The Santa María area (Fig. 4A) can clearly been subdivided into seven self-potential/elevation gradient sectors. Among these, three have positive values: M1, M2, and M4, and one, M7, is nearly flat.

The Cerro Quemado area (Fig. 4B) displays a more complex relationship between self-potential and elevation. A symmetric behavior can be seen on both side of the dome. In the center of the dome, a positive self-potential/elevation gradient (Q4) is surrounded by two non-determinable gradient areas (Q3 and Q5), then by negative self-potential/elevation gradients (Q2 and Q6), and finally bordered by straight self-potential negative peaks (Q1 and Q7-Q8).

The Samalá River and Zunil volcano area (Fig. 4C) is characterized by four sectors with only negative gradients.

\section{Discussion}

Based on the results presented above, four main points will be discussed in this chapter: (1) the main present-day hydrothermal systems active in the study area, (2) the structural discontinuities encountered along the profile, (3) the relative low amplitude fluctuation in the soil $\mathrm{CO}_{2}$ degassing, and (4) the possible location of the thermal/magmatic body responsible for the two intense geothermal zones named Zunil-I and Zunil-II.

\subsection{Main hydrothermal systems}

Our self-potential study identifies two main positive self-potential/ elevation gradients. The first one centered on top of Santa María volcano (M1/M2), and the second one within the Cerro Quemado dome (Q4). As mentioned above, these positive gradients likely delineate zones of rising hydrothermal fluids.

On the northeastern flank of Santa María volcano, the M1-M2 positive gradients suggest a hydrothermal system up to about $800 \mathrm{~m}$ away from the summit (Figs. 5 and 6). The overall self-potential signal has a typical " $\mathrm{V}$ " shape similar to the signal associated with hydrothermal systems identified on other active volcanoes (Finizola et al., 2004; Ishido, 2004; Aizawa et al., 2008). With only one selfpotential profile, it is hard to say if this hydrothermal system is fed by the thermal energy released by the residual magmatic body from the last eruption of Santa María in 1902 or by the magmatic body feeding the present-day Santiaguito dome activity, located only $2.5 \mathrm{~km}$ away from the summit of Santa María (Fig. 1C). However, the location of this hydrothermal system (see Figs. 5 and 7), located in the upper third of the edifice of Santa María, strongly suggests that the source generating the hydrothermal activity here is a residual magmatic body related to the last Santa María activity in 1902 rather than the present-day Santiaguito activity. But the main point here is that Santa María volcano is not associated with a hydrothermal system larger than about $1.5 \mathrm{~km}$ in diameter.

On Cerro Quemado dome, only one positive gradient in sector Q4 has been identified (Fig. 4). This area is associated, at the surface, with a no vegetation zone corresponding to the lava dome extrusion of 1818 (Figs. 2 and 6). These elements support the hypothesis of an underlying hydrothermal system. A $1 \mathrm{~km}$ large "transition" zone surrounds Q4, without determinable self-potential/elevation gradients (sectors Q3 and Q5), before it encounters a better-defined negative self-potential/elevation gradient suggesting downward motion of meteoric water (Fig. 6). The comparable values of the self-potential/ elevation gradients in these zones $(\mathrm{Q} 2=-0.9 \mathrm{mV} / \mathrm{m}$ and $\mathrm{Q} 6=$ $-1.1 \mathrm{mV} / \mathrm{m}$ ) and the fact that $\mathrm{Q} 2$ and $\mathrm{Q} 6$ cut the same geomorphological area bordering the Cerro Quemado dome (see the continuity of the break in slope in Figs. 1C and 2C), suggest similar lithologies in both sectors.

In the Q4 sector, the positive SP anomaly occurs within the borders of the 1818 lava dome (Fig. 6). Moreover, the positive SP/elevation gradient disappears immediately going away from the 1818 lava dome. As a consequence, we can assume that the hydrothermal system of Cerro Quemado dome is mainly delimited by the boundary of the 1818 lava dome. We therefore hypothesize that the vaporization of the present-day hydrothermal system and the rising of these hydrothermal fluids toward the surface are induced by the thermal energy released by the cooling magma of the last 1818 eruption. It is interesting to note that the extension of the Cerro Quemado hydrothermal system is no more than $1.5 \mathrm{~km}$ in diameter, similar to that beneath Santa María volcano (Figs. 5 and 6).

\subsection{Main structural discontinuities}

Previous studies comparing changes in surface topography and transitions in self-potential/elevation gradients in other volcanoes have distinguished major structural discontinuities in volcanic complexes (Tort and Finizola, 2005).

On Santa María volcano, the topography displays a sharp break in slope at the boundary between sectors M4 and M5 (Fig. 3). From a self-potential/elevation gradient point of view, M4 appears as an isolated sector with a positive value, extending only on a few hundred meters (Fig. 4A). Such marked changes in topography and selfpotential/elevation gradient suggest the presence of an important structural discontinuity. Comparing this result and previous geological surveys coupling aerial photographs and field structural geology (Foley et al., 1990; Asturias, 2003) indicates that this boundary corresponds to the border of Xela caldera (Fig. 6). In order to explain the positive self-potential/elevation gradient at this location, we hypothesize that Xela caldera is a structural boundary of higher permeability, allowing the uprising of hydrothermal fluids. It is also 


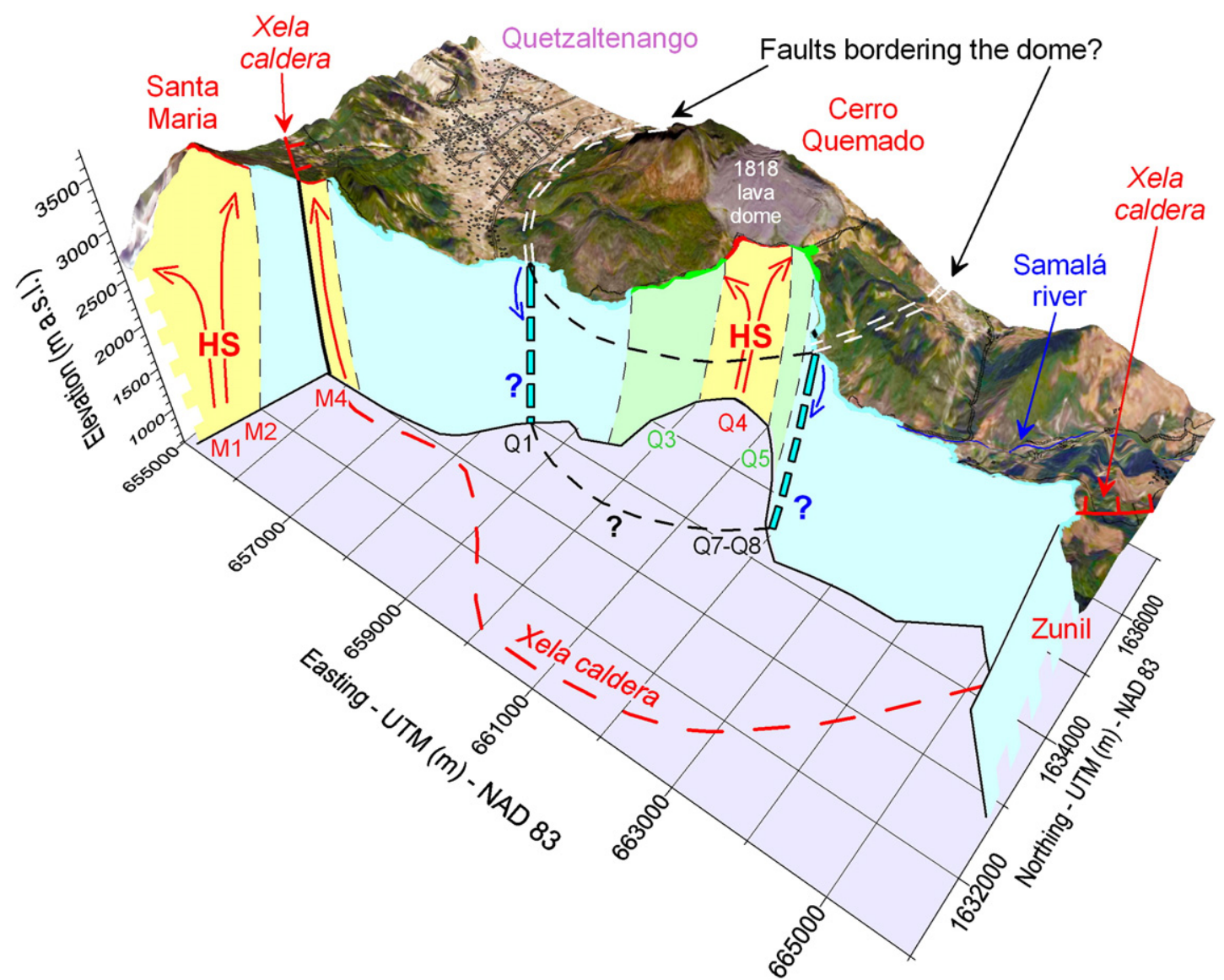

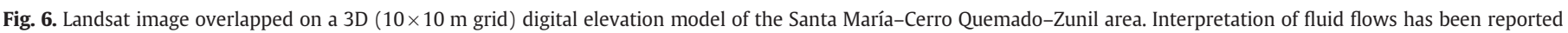

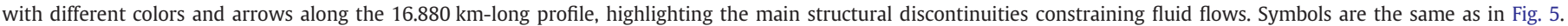
(For interpretation of the references to colour in this figure legend, the reader is referred to the web version of this article.)

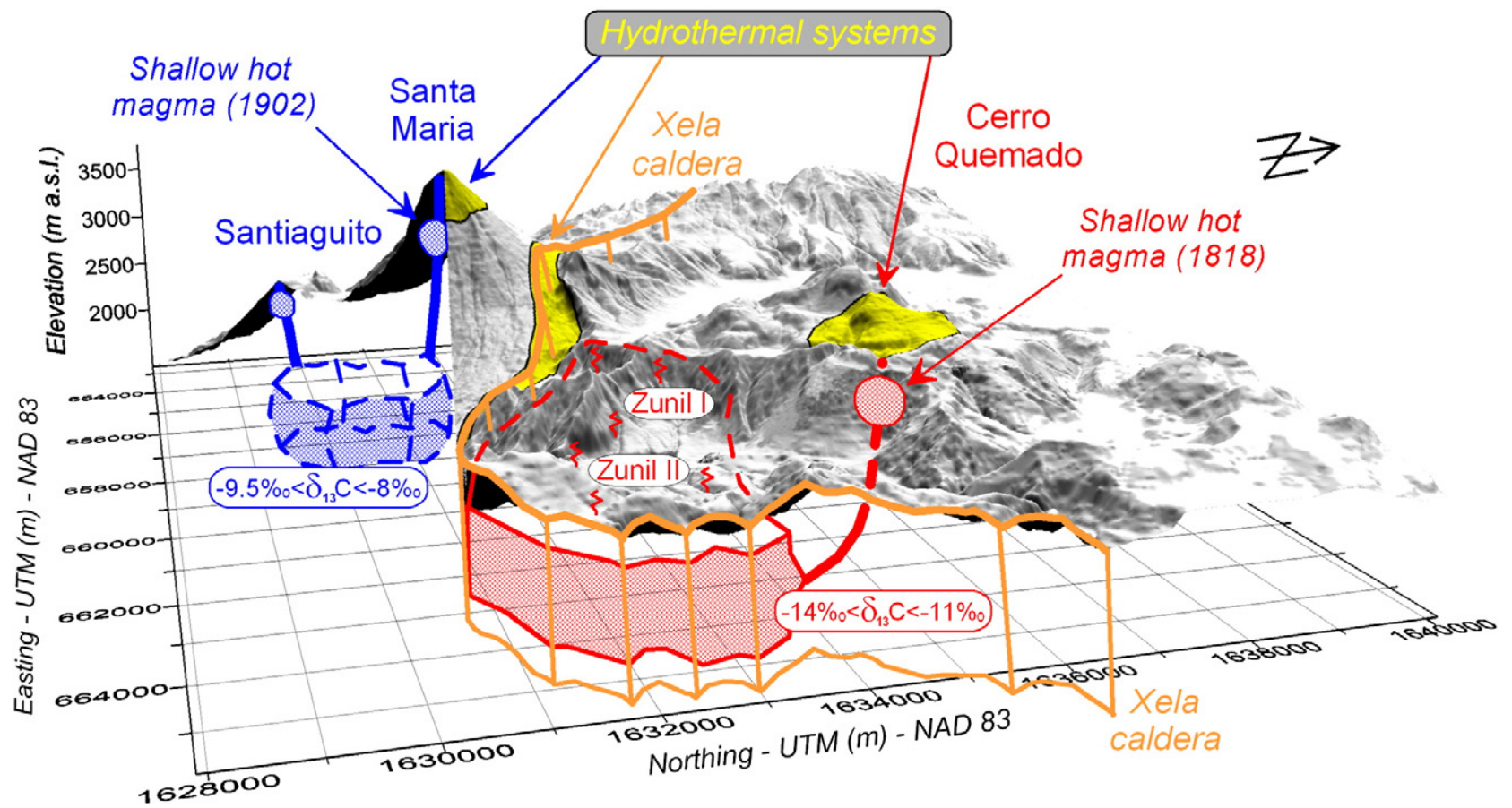

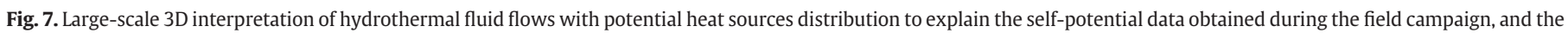
water carbon isotopic values from Walker et al. (2006). Important: depth and size of heat sources not at scale. 
important to specify that the Zunil fault zone cannot explain the M4 SP anomaly. As shown in Fig. 2C, the SP profile does not cross the Zunil fault zone. The M4 SP anomaly is located about $2 \mathrm{~km}$ away from the Zunil fault zone, and areas located closer to the Zunil fault zone (as Q2-Q3 in Figs. 2C and 3) have no positive hydrothermal SP anomaly. These geographic considerations also support our hypothesis that the M4 anomaly is linked to the Xela caldera.

The Cerro Quemado dome complex is characterized by a smoothed chaotic topography and well-defined external boundaries (Q1 and Q7 in Fig. 5). This change in morphology bordering the Cerro Quemado dome corresponds with sharp self-potential minima, but it is not associated with faults crossing the Zunil fault zone (Fig. 2). On the western side, Q1 peak could be related to a lithological transition within the dome or with bordering alluvium, but this is not likely the case on the eastern side for the Q7 and Q8 peaks. Similar short wavelength self-potential minima have been identified on Stromboli volcano and attributed to old crater boundaries through which meteoritic water preferentially flows (Finizola et al., 2002). In the case of Cerro Quemado, we are dealing with a dome complex, and dome growth is often accompanied by concentric faulting (Buisson and Merle, 2002). Therefore, the self-potential minima (Q1, Q7, and Q8) could also be interpreted as preferential rainwater infiltration along the faults induced by past stages of magma intrusion and dome growth. These dome related faults would have to be frequently reactivated for their permeability to stay high; and not be plugged by mineral precipitation. In the case of Cerro Quemado dome and due to its proximity with Quetzaltenango, it is also important to consider that such higher permeability areas bordering the dome represent weakness planes that could be used as preferential pathways for future magmatic injection in the dome complex.

\subsection{Slight fluctuations in soil $\mathrm{CO}_{2}$ degassing}

On other volcanoes, good correlations have been shown between $\mathrm{CO}_{2}$ peaks and self-potential anomalies. These have been correlated to (1) upward flow of water vapor close to heat sources and inside hydrothermal systems (Finizola et al., 2003; Lewicki et al., 2003), or with (2) downward flow of liquid water far away from heat sources and outside of hydrothermal systems (Finizola et al., 2002). In this study, no high $\mathrm{CO}_{2}$ peak is associated with the high permeability zones evidenced by the self-potential signal (e.g., Q1 and Q7-Q8 in Fig. 5). Nevertheless, the flux of soil $\mathrm{CO}_{2}$ degassing is not negligible and remains weak to medium along the profile (Fig. 3). Analyzing the $\mathrm{CO}_{2}$ signal through a FFT-low pass filter, we considered an arbitrary threshold of $10 \mathrm{~g} / \mathrm{m}^{2} \mathrm{~d}$, and then examined the $\mathrm{CO}_{2}$ minima below this value (Fig. 5). Five sectors appear to have lower $\mathrm{CO}_{2}$ flux values: $\mathrm{S} 1$, Q4, Q1, Z2, and M3. Three of them, S1, Z2, and M3, are characterized by a negative self-potential/elevation gradient and, hence, likely represent major downwellings of meteoric water. As just discussed, Q1, with its large self-potential minima, also is a likely site of downward meteoric flow. Such sites in this region are characterized by low diffuse degassing of $\mathrm{CO}_{2}$. Surface emissions of $\mathrm{CO}_{2}$ are inhibited by water-saturated soil and by the dissolution of $\mathrm{CO}_{2}$ into downward moving water (Farrar et al., 1999). The low $\mathrm{CO}_{2}$ emissions in the Q4 segment, which we have suggested is characterized by hydrothermal upwelling, are more puzzling. Finizola et al. (2002) saw a similar correlation between low $\mathrm{CO}_{2}$ emanations and hydrothermal upwelling within Stromboli volcano, which they attributed to self-sealing of the hydrothermal system, which inhibits the release of $\mathrm{CO}_{2}$. This would also explain the very low level of fumarolic activity at Cerro Quemado. To conclude, our study area has a medium level of $\mathrm{CO}_{2}$ diffuse degassing except where there is preferential water infiltration, as at the boundaries of the Xela caldera, and above the hydrothermal system at Cerro Quemado. These ideas need to be tested by additional surveys, for example by coupling resistivity tomography with SP and soil gas measurements, along new profiles crossing the entire region, like Barde-Cabusson et al. (2009b) did in Italy, on Vulcano edifice.

\subsection{Thermal/magmatic body related to Zunil-I and Zunil-II}

The results of the present study make possible to better constrain the ongoing debate about the thermal/magmatic source responsible for the Zunil-I and Zunil-II geothermal activities.

Although our self-potential profile did not reach the top of Zunil volcano, no hydrothermal system signature has been shown on the northern flank of Zunil, between 2050 and 2800 masl (Fig. 4C). It is therefore difficult to attribute the Zunil-I and Zunil-II fumarolic manifestations to a magma body beneath Zunil volcano as suggested by Giggenbach et al. (1992). On the other hand, the Santa María and Cerro Quemado dome hydrothermal systems have diameters of less than $1.5 \mathrm{~km}$, centered on the edifices. This fact is not in accordance with the hypothesis of Barmin et al. (2002) that posits an extensive hydrothermal system linked to Santa María-Santiaguito to explain both the Zunil-I and Zunil-II geothermal areas. Carbon isotopic data presented by Walker et al. (2006) are also inconsistent with these hypotheses, and suggest a preferential link between Cerro Quemado and the Zunil-I and Zunil-II geothermal areas. Our survey also puts constraints on this suggestion.

As shown on a larger scale (Fig. 7), the Zunil-I and Zunil-Il geothermal areas are located inside a highly complex tectonic area, called the Zunil fault zone, parallel and close to the eastern border of Xela caldera. This caldera boundary channels hydrothermal fluids within the Santa María edifice (sector M4 in Figs. 5 and 6). Our data suggest that the historical volcanic activity of Santa María and Cerro Quemado only produces small hydrothermal systems, with restricted lateral extensions. Indeed, it is difficult to imagine a deep heat source for Cerro Quemado and Santa María, able to produce hydrothermal systems with a relatively small lateral extension (only $1.5 \mathrm{~km}$ in diameter). On the other hand, the positioning of the Zunil-I and Zunil-II, aligned along deep tectonic structures (Zunil fault zone), may suggest a deeper heat source. We therefore hypothesize the existence of a deeper and broader heat source to explain the intense geothermal manifestations observed at the Zunil-I and Zunil-II geothermal sites, and shallower heat sources, related to recent historical eruptive activity, to explain the hydrothermal systems of Cerro Quemado and Santa María (Fig. 7). The heat source of Zunil-I and Zunil-II could be a remnant of the Xela caldera system with fluid flow focused into the highly fractured Zunil area. Hot fluids rising along the caldera rim could be distributed by the highly fracturated ring fault system, as occurs in other caldera-related geothermal systems of Central America, such as the Concepción de Ataco caldera, the Ahuachapan Geothermal Systems (González Partida et al., 1997), and the Berlin Caldera and Berlin Geothermal System (D'Amore and Tenorio Mejia, 1999), both in El Salvador. This Xela heat source could also be responsible for the hypothesized hydrothermal fluid flow on the northeastern flank of Santa María (segment M4) and even that at Cerro Quemado, which would be in accordance with the carbon isotopic resemblance between water samples at Cerro Quemado and Zunil (Fig. 7) (Walker et al., 2006).

\section{Conclusions}

Contrary to other self-potential surveys carried out on Andean volcanoes that identified huge hydrothermal systems more than $6 \mathrm{~km}$ in diameter (Finizola et al., 2004), our survey crossing Santa María, Cerro Quemado, and Zunil volcanic complexes only identified 2-3 small, active hydrothermal systems no more than $1.5 \mathrm{~km}$ in diameter: one located below the top of Santa María; another on the northwestern flank of Santa María; and one located in the upper part of the Cerro Quemado dome complex. The restricted lateral extensions for these hydrothermal systems do not support existing hypotheses of the subsurface linkages 
between the volcanic complexes and the intense Zunil-I and Zunil-II geothermal manifestations. Therefore, we have to consider a deeper and more extensive heat source/magmatic body to explain the Zunil-I and Zunil-II geothermal sites located inside Xela caldera. Such a heat source would also explain the hydrothermal fluid rising along the Xela caldera boundary as suggested by the new self-potential survey. Due to the similar carbon isotopic ratios in water between Cerro Quemado and the Zunil-I and Zunil-II areas (Walker et al., 2006), we also hypothesize that the hydrothermal/volcanic activity at Cerro Quemado corresponds to a lateral extension of the heat source/magmatic body feeding the Zunil fault zone. Considering a large active magmatic system inside the Xela caldera, we can also better understand the near homogeneous $\mathrm{CO}_{2}$ degassing inside the caldera, and the decrease of the $\mathrm{CO}_{2}$ flux values outside the caldera boundaries.

Further multidisciplinary surveys such as those carried out on Vulcano Island by Barde-Cabusson et al. (2009a,b) where they coupled resistivity tomography, SP and soil gas measurements would be useful to better image the complex relationship between the volcano-tectonic structures and heat sources responsible for the Zunil-I and Zunil-II geothermal areas, because those three methods are all highly sensitive to fluid flow, highlighting preferential structures used for fluid circulation within volcanic edifices. From a hazard point of view, it is possible that an important seismo-tectonic event could disrupt the hydro-magmatic equilibrium in the Zunil fault zone. On the Cerro Quemado dome complex, new magma injections would likely occur along the highest permeability areas bordering the dome and near the heavily populated city of Quetzaltenango.

\section{Acknowledgements}

This survey was supported by a National Oceanic and Atmospheric Administration (NOAA) grant operated through the Analytical Center for Climate and Environmental Change (ACCEC) in the Department of Geology and Environmental Geosciences, Northern Illinois University, and in collaboration with the Universidad de El Salvador. We particularly appreciated the assistance of Barry Cameron and Kurt Roggensack in the field. The authors thank the local civil defense institution from Cantel, which ensured security during the fieldwork. We are very thankful to Bill Rose for the digital elevation model exchanges we made. We would like to thank the two anonymous reviewers for their greatly appreciated constructive comments. This is IPGP contribution number 2571.

\section{References}

Adams, M.C., Mink, L.L., Moore, J.N., White, L.D., Caicedo Anchissi, A., 1990. Geochemistry and hydrology of the Zunil geothermal system, Guatemala Geotherm. Resour. Counc. Trans. 14, 837-844.

Aizawa, K., 2008. Classification of self-potential anomalies on volcanoes and possible interpretations for their subsurface structure. J. Volcanol. Geotherm. Res. 175, 253-268. doi:10.1016/j.jvolgeores.2008.03.011.

Aizawa, K., Uyeshima, M., Nogami, K., 2008. Zeta potential estimation of volcanic rocks on 11 island arc-type volcanoes in Japan: implication for the generation of local self-potential anomalies. J. Geophys. Res. 113, B02201. doi:10.1029/2007JB005058.

Allard, P., Carbonnelle, J., Dajlevic, D., Le Bronec, J., Morel, P., Robe, M.C., Maurenas, J.M., Faivre-Pierret, R., Martin, D., Sabroux, J.C., Zettwoog, P., 1991. Eruptive and diffuse emissions of $\mathrm{CO}_{2}$ from Mount Etna. Nature 351, 387-391.

Anderson, S.W., Fink, J.H., Rose, W.I., 1995. Mount St. Helens and Santiaguito lava domes: the effect of short-term eruption rate on surface texture and degassing processes. J. Volcanol. Geotherm. Res. 69, 105-116.

Asturias, F., 2003. Reservoir assessment of Zunil I and II geothermal fields, Guatemala. Geothermal Training Program 3. The United Nations University, pp. 1-32.

Aubert, M., Kieffer, G., 1984. Evolution d'une intrusion magmatique dans le flanc Sud de l'Etna entre juin 1982 et juin 1983. Résultats de potentiel spontané (PS) et essai d'interprétation de l'éruption de 1983. C. R. Acad. Sci. Paris Sér. 293, 379-382.

Ball, L., Ge, S., Caine, J.S., Revil, A., Jardani, A., 2010. Constraining fault-zone hydrogeology through integrated hydrological and geoelectrical analysis. Hydrogeol. J. 18, 1057-1067. doi:10.1007/s10040-010-0587-z.

Barde-Cabusson, S., Levieux, G., Lénat, J.-F., Finizola, A., Revil, A., Chaput, M., Dumont, S. Duputel, Z., Guy, A., Mathieu, L., Saumet, S., Sorbadère, F., Vieille, M., 2009a. Transient self-potential anomalies associated with recent lava flows at Piton de la
Fournaise volcano (Réunion Island, Indian Ocean). J. Volcanol. Geotherm. Res. 187, 158-166. doi:10.1016/j.jvolgeores.2009.09.003.

Barde-Cabusson, S., Finizola, A., Revil, A., Ricci, T., Piscitelli, S., Rizzo, E., Angeletti, B., Balasco, M., Bennati, L., Byrdina, S., Carzaniga, N., Crespy, A., Di Gangi, F., Morin, J., Perrone, A., Rossi, M., Roulleau, E., Suski, B., Villeneuve, N., 2009b. New geological insights and structural control on fluid circulation in La Fossa cone (Vulcano, Aeolian Islands, Italy). J. Volcanol. Geotherm. Res. 185, 231-245. doi:10.1016/j.jvolgeores.2009.06.002.

Barmin, A., Melnik, O., Sparks, R.S.J., 2002. Periodic behavior in lava dome eruptions. Earth Planet. Sci. Lett. 199, 173-184.

Brueckner, H.K., Avé Lallemant, H.G., Sisson, V.B., Harlow, G.E., Hemming, S.R., Martens, U., Tsujimori, T., Sorensen, S.S., 2009. Metamorphic reworking of a high pressurelow temperature mélange along the Motagua fault, Guatemala: a record of neocomian and Maastrichtian transpressional tectonics. Earth Planet. Sci. Lett. 284, 228-235. doi:10.1016/j.epsl.2009.04.032.

Buisson, C., Merle, O., 2002. Experiments on internal strain in lava dome cross sections. Bull. Volcanol. 64, 363-371. doi:10.1007/s00445-002-0213-6.

Cáceres, D., Monterroso, D., Tavakoli, B., 2005. Crustal deformation in northern Central America. Tectonophysics 404, 119-131. doi:10.1016/j.tecto.2005.05.008.

Caicedo Anchissi, A., Palma, J., 1990. Present status of exploration and development of the geothermal resources of Guatemala. Geotherm. Resour. Counc. Trans. 14, 97-105.

Carr, M.J., 1984. Symmetrical and segmented variation of physical and geochemical characteristics of the Central American volcanic front. J. Volcanol. Geotherm. Res. 20, 231-252.

Carr, M.J., Rose, W.I., Stoiber, R.E., 1982. Central America. In: Thorpe, R.S. (Ed.), Andesites. John Wiley, New York, pp. 149-166.

Cartagena, R., Olmos, R., López, D.L., Soriano, T., Barahona, F., Hernandez, P.A., Pérez, N.M., 2004. Diffuse soil degassing of carbon dioxide, radon, and mercury at San Miguel volcano, El Salvador. In: Rose, W.I., Bommer, J.J., López, D.L., Carr, M.J., Major, J.J. (Eds.), Natural hazards in El Salvador: Boulder, Colorado, Geological Society of America Special Paper. 375, pp. 203-212.

Chiodini, G., Frondini, F., Raco, B., 1996. Diffuse emission of $\mathrm{CO}_{2}$ from the Fossa crater, Vulcano Island (Italy). Bull. Volcanol. 85, 41-50.

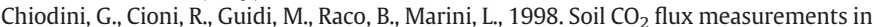
volcanic and geothermal areas. Appl. Geochem. 13 (5), 543-552.

Conway, F.M., Vallance, J.W., Rose, W.I., Johns, G.W., Paniagua, S., 1992. Cerro Quemado, Guatemala: the volcanic history and hazards of an exogenous volcanic dome complex. J. Volcanol. Geotherm. Res. 52 (4) 303-308, 311-323.

Conway, F.M., Diehl, J.F., Rose, W.I., Matias, O., 1994. Age and magma flux of Santa María volcano, Guatemala: correlation of paleomagnetic waveforms with the 28,000 to 25,000 yr B.P. Mono Lake excursion. Geology 102, 11-24.

Corwin, R.F., Hoover, D.B., 1979. The Self-Potential method in geothermal exploration. Geophysics 44, 226-245.

Cox, R.T. Lumsden, D.N., Gough, K., Lloyd, R., Talnagi, J., 2008. Investigation of late Quaternary fault uplift along the Motagua/Swan Islands fault system: implications for seismic/tsunami hazard for the Bay of Honduras. Tectonophysics 457, 30-41. doi:10.1016/j.tecto.2008.05.014

D'Amore, F.D., Tenorio Mejia, J., 1999. Chemical and physical reservoir parameters at initial conditions in Berlin geothermal field, El Salvador: a first assessment. Geothermics 28, 45-73.

DeMelts, C., 2001. A new estimate for present-day Cocos-Caribbean plate motion: implications for slip along the Central American volcanic arc. Geophys. Res. Lett. 28 (21), 4043-4046.

DeMelts, C., Jansma, P.E., Mattioli, G.S., Dixon, T.H., Farina, F., Bilham, R., Calais, E., Mann, P., 2000. GPS geodetic constraints on Caribbean-North America plate motion. Geophys. Res. Lett. 27, 437-440

Donnelly, T.W., Horne, G.S., Finch, R.C., López-Ramos, E., 1990. Northern Central America: the Maya and Chortís blocks. In: Dengo, G., Case, J.E. (Eds.), The Caribbean region: Boulder, Colorado, Geological Society of America, The Geology of North America. H, pp. 37-76.

Duffield, W., Heiken, G., Foley, D., McEwen, A., 1993. Oblique synoptic images, produced from digital data, display strong evidence of a "new" caldera in south-western Guatemala. J. Volcanol. Geotherm. Res. 55 (3-4), 217-224.

Escobar-Wolf, R.P., Diehl, J.F., Singer, B.S., Rose, W.I., 2010. ${ }^{40} \mathrm{Ar} /{ }^{39} \mathrm{Ar}$ and paleomagnetic constraints on the evolution of Volcán de Santa María, Guatemala. GSA Bull. 122 (5-6), 757-771. doi:10.1130/B26569.1.

Etiope, G., Beneduce, P., Calcara, M., Favali, P., Frugoni, F., Schiattarella, M., Smriglio, G., 1999. Structural pattern and $\mathrm{CO}_{2}-\mathrm{CH}_{4}$ degassing of Ustica island, Southern Tyrrhenian basin. J. Volcanol. Geotherm. Res. 88, 291-304.

Farrar, C.D., Neil, J.M., Howle, J.F., 1999. Magmatic carbon emissions at Mammoth Mountain, California. U.S. Geol. Survey Water-Resources Investigations Report. 98-4217.

Finizola, A., Sortino, F., Lénat, J.-F., Valenza, M., 2002. Fluid circulation at Stromboli volcano (Aeolian Islands, Italy) from self-potential and $\mathrm{CO}_{2}$ surveys. J. Volcanol. Geotherm. Res. 116, 1-18.

Finizola, A., Sortino, F., Lénat, J.-F., Aubert, M., Ripepe, M., Valenza, M., 2003. The summit hydrothermal system of Stromboli. New insights from self-potential, temperature, $\mathrm{CO}_{2}$ and fumarolic fluid measurements, with structural and monitoring implications. Bull. Volcanol. 65 (7), 486-504.

Finizola, A., Lénat, J.-F., Macedo, O., Ramos, D., Thouret, J.-C., Sortino, F., 2004. Fluid circulation and structural discontinuities inside Misti volcano (Peru) inferred from self-potential measurements. J. Volcanol. Geotherm. Res. 135 (4), 343-360.

Finizola, A., Revil, A., Rizzo, E., Piscitelli, S., Ricci, T., Morin, J., Angeletti, B., Mocochain, L., Sortino, F., 2006. Hydrogeological insights at Stromboli volcano (Italy) from geoelectrical, temperature, and $\mathrm{CO}_{2}$ soil degassing investigations. Geophys. Res. Lett. 33, L17304. doi:10.1029/2006GL026842.

Finizola, A., Aubert, M., Revil, A., Schütze, C., Sortino, F., 2009. Importance of structural history in the summit area of Stromboli during the 2002-2003 eruptive crisis inferred 
from temperature, soil $\mathrm{CO}_{2}$, self-potential, and electrical resistivity tomography. J. Volcanol. Geotherm. Res. 183, 213-227. doi:10.1016/j.jvolgeores.2009.04.002.

Foley, D., Moore, J.N., Lutz, S.J., Palma, J.C., Ross, H.P., Tobias, E., Tripp, A.C., 1990. Geology and geophysics of the Zunil geothermal system, Guatemala. Geotherm. Resour. Counc. Trans. 14, 1405-1412.

Frank, D., 1995. Surficial extent and conceptual model of hydrothermal system at Mount Rainier, Washington. J. Volcanol. Geotherm. Res. 65, 51-80. doi:10.1016/0377-0273 (94)00081-Q.

Gerlach, T., Doukas, M., McGee, K., Kessler, R., 1998. Three-year decline of magmatic $\mathrm{CO}_{2}$ emission from soils of a Mammoth Mountain tree kill: Horseshoe Lake, CA, 19951997. Geophys. Res. Lett. 25, 1947-1950.

Giggenbach, W.F., Garcia, N., Londoño, A., Rodriguez, L., Rojas, N., Calvache, M.L., 1990. The chemistry of fumarolic vapor and thermal-spring discharges from the Nevado del Ruiz volcanic-magmatic-hydrothermal system, Colombia. J. Volcanol. Geotherm. Res. 42, 13-39.

Giggenbach, W.F., Paniagua de Gudiel, D., Roldan Manzo, A.R., 1992. Isotopic and chemical composition of water and gas discharges from the Zunil geothermal system, Guatemala. Estudios Geotérmicos con Técnicas Isotópicas y Geoquímicas en America Latina. Organismo Internacional de Energía Atómica, Vienna, pp. 245-278.

Giunta, G., Beccaluva, L., Coltorti, M., Mortellaro, D., Siena, F., Cutrupia, D., 2002. The peri-Caribbean ophiolites: structures, tectono-magmatic significance and geodynamic implications. Caribb. J. Earth Sci. 36, 1-20.

González Partida, E., Torres Rodriguez, V., Birkle, P., 1997. Plio-pleistocene volcanic history of the Ahuachapán geothermal system, El Salvador: the Concepción de Ataco Caldera. Geothermics 26, 555-575.

Granieri, D., Carapezza, M.L., Chiodini, G., Avino, R., Caliro, S., Ranaldi, M., Ricci, T., Tarchini, L., 2006. Correlated increase in $\mathrm{CO}_{2}$ fumarolic content and diffuse emission from la Fossa crater (Vulcano, Italy): evidence of volcanic unrest or increasing gas release from a stationary deep magma body? Geophys. Res. Lett. 33, L13316. doi:10.1029/2006GL026460.

Harris, A.J.L., Flynn, L.P., Matias, O., Rose, W.I., 2002. The thermal stealth flows of Santiaguito dome, Guatemala: implications for the cooling and emplacement of dacitic block-lava flows. Geol. Soc. Am. Bull. 114, 533-546.

Harris, A.J.L., Rose, W.I., Flynn, L.P., 2003. Temporal trends in lava dome extrusion at Santiaguito 1922-2000. Bull. Volcanol. 65 (2-3), 77-89.

Harris, A.J.L., Flynn, L.P., Matias, O., Rose, W.I., Cornejo, J., 2004. The evolution of an active silicic lava flow field: an ETM perspective. J. Volcanol. Geotherm. Res. 135 (1-2), $147-168$.

Henley, R.W., Ellis, A.J., 1983. Geothermal systems ancient and modern: a geochemical review. Earth Sci. Rev. 19, 1-50.

Hernández, P.A., Pérez, N.M., Salazar, J.M., Notsu, K., Wakita, H., 1998. Diffuse emission of carbon dioxide, methane, and helium-3 from Teide volcano, Tenerife, Canary Islands. Geophys. Res. Lett. 25, 3311-3314.

Hernández, P.A., Salazar, J.M., Shimoike, Y., Mori, T., Notsu, K., Pérez, N.M., 2001. Diffuse emission of $\mathrm{CO}_{2}$ from Miyakejima volcano, Japan. Chem. Geol. 177, 175-185.

Ishido, T., 2004. Electrokinetic mechanism for the "W"-shaped self-potential profile on volcanoes. Geophys. Res. Lett. 31, L15616. doi:10.1029/2004GL020409.

Jackson, D.B., Kauahikaua, J., 1987. Regional self-potential anomalies at Kilauea volcano: "Volcanism in Hawaii" chapter 40. U.S. Geol. Surv. Prof. Pap. 1350, 947-959.

Kanamori, H., Stewart, G.S., 1978. Seismological aspects of the Guatemala earthquake of February 4, 1976. J. Geophys. Res. 83, 3427-3434.

Keppie, J.D., 2004. Terranes of Mexico revisited: a 1.3 billion year odyssey. Int. Geol. Rev. 46, 765-794.

Lénat, J.-F., 1987. Structure et dynamique interne d'un volcan basaltique intraplaque océanique: Le Piton de la Fournaise (île de la Réunion). Thèse de doctorat ès sciences. Univ. Blaise Pascal, Clermont-Ferrand (France).

Lénat, J.-F., Robineau, B., Durand, S., Bachèlery, P., 1998. Etude de la zone sommitale du volcan Karthala (Grande Comore) par polarisation spontanée. C. R. Acad. Sci. 327. 781-788.

Lewicki, J.L., Connor, C., St-Amand, K., Stix, J., Spinner, W., 2003. Self-potential, soil $\mathrm{CO}_{2}$ flux, and temperature on Masaya volcano, Nicaragua. Geophys. Res. Lett. 30 (15). doi:10.1029/2003GL017731 1817, 1-4.

Lima Lobato, E.M., Palma, J., 2000. The Zunil-II geothermal field, Guatemala, Central America. Proceedings of the World Geothermal Congress, Tohoku, Japan, pp. 2133-2138.

Lopez, D.L., Williams, S.N., 1993. Catastrophic volcanic collapse: relation to hydrothermal processes. Science 260, 1794-1796.

Lopez, D.L., Ransom, L., Perez, N., Hernandez, P., Monterrosa, J., 2004. Dynamics of diffuse degassing at Ilopango Caldera, El Salvador. In: Rose, W.I., Bommer, J.J., López, D.L., Carr, M.J., Major, J.J. (Eds.), Geological Society of America Special Paper No. 375 "Natural Hazards in El Salvador", pp. 191-202.

Lorne, B., Perrier, F., Avouac, J.-P., 1999a. Streaming potential measurements, 1, Properties of the electrical double layer from crushed rock samples. J. Geophys. Res. 104, 17,857-17,877.

Lorne, B., Perrier, F., Avouac, J.-P., 1999b. Streaming potential measurements, 2 Relationship between electrical and hydraulic flow patterns from rock samples during deformation. J. Geophys. Res. 104, 17,879-17,896.

MacInnes, D.A., 1961. The Principles of Electrochemistry. Reinhold Publishing Company, Dover Publications, New York.

Mahar, A., Lagmay, F.A., Tengonciang, A.M.P., Marcos, H.V., Pascua, C.S., 2003. A structural model guide for geothermal exploration in Ancestral Mount Bao, Leyte, Philippines. J. Volcanol. Geotherm. Res. 122, 133-141.

Malengreau, B., Lénat, J.-F., Bonneville, A., 1994. Cartographie et surveillance temporelle des anomalies de Polarisation Spontanée (PS) sur le Piton de la Fournaise. Bull. Soc. Géol. Fr. 165, 221-232.

McBirney, A.R., 1963. Geology of a part of the central Guatemalan Cordillera. Calif. Univ. Publ. Geol. Sci. 38, 177-242.
Muller, R.D., Sdrolias, M., Gaina, C., Roest, W.R., 2008. Age, spreading rates and spreading symmetry of the world's ocean crust. Geochem. Geophys. Geosyst. 9, Q04006. doi:10.1029/2007GC001743.

Negraru, P.T., Blackwell, D.D., Erkan, K., 2008. Heat flow and geothermal potential in the South-Central United States. Nat. Resour. Res. 17 (4), 227-243.

Newhall, C.G., 1987. Geology of the Lake Atitlán Region, Western Guatemala. J. Volcanol. Geotherm. Res. 33 (1-3), 23-55. doi:10.1016/0377-0273(87)90053-9.

Nieva, D., Verma, M.P., Santoyo, E., Portugal, E., Campos, A., 1997. Geochemical exploration of the Chipilapa Geothermal Field, El Salvador. Geothermics 26, 589-612.

Onizawa, S., Matsushima, N., Ishido, T., Hase, H., Takakura, S., Nishi, Y., 2009. Self-potential distribution on active volcano controlled by three-dimensional resistivity structure in Izu-Oshima, Japan. Geophys. J. Int. 178, 1164-1181. doi:10.1111/j.1365-246X 2009.04203.x.

Ortega-Gutiérrez, F., Ruiz, J., Centeno-García, E., 1995. Oaxaquia, a Proterozoic microcontinent accreted to North America during the late Paleozoic. Geology 23, 1127-1130.

Ortega-Gutiérrez, F., Solari, L.A., Ortega-Obregón, C., Elías-Herrera, M., Martens, U. Morán-Icál, S., Chiquín, M., Keppie, J.D., Torres de León, R., Schaaf, P., 2007. The Maya-Chortís boundary: a tectonostratigraphic approach. Int. Geol. Rev. 49 (11) 996-1024.

Ortega-Obregón, C., Solari, L.A., Keppie, J.D., Ortega-Gutiérrez, F., Solé, J., Morán-Ical, S. 2008. Middle-Late Ordovician magmatism and Late Cretaceous collision in the southern Maya block, Rabinal-Salamá area, central Guatemala: implications for North America-Caribbean plate tectonics. Geol. Soc. Am. Bull. 120 (5-6), 556-570. doi:10.1130/B26238.1.

Overbeek, J.T.G., 1952. Electrochemistry of the double layer. In: Kruyt, H.R. (Ed.), Colloid Science. Irreversible Systems. 1. Elsevier Sci, New York, pp. 115-193.

Pérez, N.M., Salazar, J.M.L., Hernández, P.A., Olmos, R., Barahona, F., Cartagena, R. Soriano, T., Lopez, D.L., Notsu, K., 2004. Diffuse $\mathrm{CO}_{2}$ and ${ }^{222} \mathrm{Rn}$ degassing from San Salvador volcano, El Salvador, Central America. In: Rose, W.I., Bommer, J.J., López, D.L., Carr, M.J., Major, J.J. (Eds.), Geological Society of America Special Paper No. 375 "Natural Hazards in El Salvador", pp. 227-236.

Phipps Morgan, J., Ranero, C.R., Vannucchi, P., 2008. Intra-arc extension in Central America: links between plate motions, tectonics, volcanism, and geochemistry. Earth Planet. Sci. Lett. 272, 365-371. doi:10.1016/j.epsl.2008.05.004.

Pribnow, D.F.C., Schütze, C., Hurter, S.J., Flechsig, C., Sass, J.H., 2003. Fluid flow in the resurgent dome of Long Valley Caldera: implications from thermal data and deep electrical sounding. J. Volcanol. Geotherm. Res. 127, 329-345.

Reid, M.E., 2004. Massive collapse of volcano edifices triggered by hydrotherma pressurization. Geology 32, 373-376. doi:10.1130/G20300.1.

Reid, M.E., Sisson, T.W., Brien, D.L., 2001. Volcano collapse promoted by hydrothermal alteration and edifice shape, Mount Rainier, Washington. Geology 29, 779-782. doi:10.1130/0091-7613(2001) 029.

Revil, A., 2002. Comment on "Rapid fluid disruption: A source for self-potential anomalies on volcanoes" by M.J.S. Johnston, J.D. Byerlee, and D. Lockner. J. Geophys. Res. 107 (B8). doi:10.1029/2002JB001794.

Revil, A., Cathles, L.M., 2002a. Fluid transport by solitary waves along growing faults: a field example from the South Eugene Island Basin, Gulf of Mexico. Earth Planet. Sci. Lett. 202 (2), 321-335.

Revil, A., Cathles, L.M., 2002b. Erratum: fluid transport by solitary waves along growing faults: a field example from the South Eugene Island Basin, Gulf of Mexico. Earth Planet. Sci. Lett. 204 (1-2), 321-322.

Revil, A., Leroy, P., 2001. Hydroelectric coupling in a clayey material. Geophys. Res. Lett. 28, 1643-1646.

Revil, A., Pezard, P.A., Glover, P.W.J., 1999a. Streaming potential in porous media. 1. Theory of the zeta potential. J. Geophys. Res. 104, 20,021-20,031.

Revil, A., Schwaeger, H., Cathles, L.M., Manhardt, P.D., 1999b. Streaming potential in porous media. 2. Theory and application to geothermal systems. J. Geophys. Res. $104,20,033-20,048$

Revil, A., Finizola, A., Sortino, F., Ripepe, M., 2004. Geophysical investigations at Stromboli volcano, Italy: implications for ground water flow and paroxysmal activity. Geophys. J. Int. 157, 426-440. doi:10.1111/j.1365-246X.2004.02181.x.

Revil, A., Finizola, A., Piscitelli, S., Rizzo, E., Ricci, T., Crespy, A., Angeletti, B., Balasco, M., Barde Cabusson, S., Bennati, L., Bolève, A., Byrdina, S., Carzaniga, N., Di Gangi, F., Morin, J., Perrone, A., Rossi, M., Roulleau, E., Suski, B., 2008. Inner structure of La Fossa di Vulcano (Vulcano Island, southern Tyrrhenian Sea, Italy) revealed by highresolution electric resistivity tomography coupled with self-potential, temperature and $\mathrm{CO}_{2}$ diffuse degassing measurements. J. Geophys. Res. 113, B07207. doi:10.1029/2007JB005394.

Rogers, R.D., 2003. Jurassic-Recent tectonic and stratigraphic history of the Chortis block of Honduras and Nicaragua (northern Central America). The University of Texas at Austin, Ph.D., dissertation, 289 pp.

Rose, W.I., 1972a. Notes on the 1902 eruption of Santa María volcano, Guatemala. Bull. Volcanol. 36, 29-45.

Rose, W.I., 1972b. Santiaguito volcanic dome, Guatemala. Geol. Soc. Am. Bull. 83 1413-1434.

Rose, W.I., 1973. Pattern and mechanism of volcanic activity at the Santiaguito volcanic dome, Guatemala. Bull. Volcanol. 37 (1), 73-94.

Rose, W.I., 1974. Nuée ardente from Santiaguito volcano, April, 1973. Bull. Volcanol. 37, 365-371.

Rose, W.I., 1987a. Volcanic activity at Santiaguito volcano, 1976-1984. In: Fink, J.H. (Ed.), The emplacement of silicic domes and lava flows: Geol. Soc. Am. Spec. Paper, 212, pp. 17-27.

Rose, W.I., 1987b. Santa María, Guatemala: bimodal soda-rich calc-alkalic stratovolcano. J. Volcanol. Geotherm. Res. 33 (1-3), 109-129.

Rose, W.I., Grant, N.K., Hahn, G.A., Lange, I.M., Powell, J.L., Easter, J., DeGraff, J.M., 1977a The evolution of Santa María volcano, Guatemala. Geology 85, 63-87. 
Rose, W.I., Pearson, T., Bonis, S., 1977b. Nuée ardente eruption from the foot of a dacite lava flow. Bull. Volcanol. 40 (1), 23-38.

Rose, W.I., Conway, F.M., Pullinger, C.R., Deino, A., McIntosh, W.C., 1999. An improved age framework for late Quaternary silicic eruptions in northern Central America. Bull. Volcanol. 61, 106-120. doi:10.1007/s004450050266.

Rosencrantz, E., Mann, P., 1991. SeaMARC II mapping of transform faults in the Cayman Trough, Caribbean Sea. Geology 19, 690-693.

Sanchez Bennett, E., Rose, W.I., Conway, F.M., 1992. Santa María, Guatemala: a decade volcano. EOS (Trans. Am. Geophys. Union) 73, 521-522.

Scheffer, F., Schachtschabel, P., 1989. Lehrbuch der Bodenkunde. Enke-Verlag, Stuttgart. $491 \mathrm{pp}$.

Stoiber, R.E., Carr, M.J., 1973. Quaternary volcanic and tectonic segmentation of Central America. Bull. Volcanol. 37, 304-325.

Stoiber, R.E., Rose, W.I., 1969. Recent volcanic and fumarolic activity at Santiaguito volcano, Guatemala. Bull. Volcanol. 33, 475-502.

Stoiber, R.E., Rose, W.I., 1970. The geochemistry of Central American volcanic gas condensates. Geol. Soc. Am. Bull. 81, 2851.

Stoiber, R.E., Rose, W.I., 1974. Fumarole incrustations at active Central American volcanoes. Geochim. Cosmochim. Acta 38 (4), 495-516.

Templeton, S., 1999. Hydrothermal systems at Volcan Santa María, Guatemala. M.S thesis, DeKalb, Illinois, Northern Illinois University, 166 pp.

Todesco, M., 1997. Origin of fumarolic fluids at Vulcano (Italy). Insights from isotope data and numerical modeling of hydrothermal circulation. J. Volcanol. Geotherm. Res. 79, 63-85.

Tort, A., Finizola, A., 2005. The buried caldera of Misti volcano, Peru, revealed by combining a self-potential survey with elliptic Fourier function analysis of topography. J. Volcanol. Geotherm. Res. 141, 283-297. doi:10.1016/j.jvolgeores.2004.11.005.
Van Wyk de Vries, B., Kerle, N., Petley, D., 2000. Sector collapse forming at Casita volcano, Nicaragua. Geology 28, 167-170.

Varley, N.R., Armienta, M.A., 2001. The absence of diffuse degassing at Popocatépetl volcano, Mexico. Chem. Geol. 177, 157-173.

Walker, J.A., Templeton, S., Cameron, B.I., 2006. The chemistry of spring waters and fumarolic gases encircling Santa María volcano, Guatemala: insights into regional hydrothermal activity and implications for volcano monitoring. In: Rose, W.I., Bluth, G.J.S., Carr, M.J., Ewert, J., Patino, L.C., Vallance, J.V. (Eds.), Volcanic hazards in Central America: Geol. Soc. America Special Paper. 412, pp. 59-83. doi:10.1130/2006.2412(04).

Weber, B., Schaaf, P., Valencia, V.A., Iriondo, A., Ortega-Gutiérrez, F., 2006. Provenance ages of late Paleozoic sandstones (Santa Rosa Formation) from the Maya block, SE Mexico. Implications on the tectonic evolution on western Pangea. Rev. Mex. Cienc. Geol. 23 (3), 262-276.

Weyl, R., 1980. Geology of Central America. Gebruder Borntraeger, Berlin. 371 pp.

White, R.A., 1985. The Guatemala earthquake of 1816 on the Chixoy-Polochic fault. Bull. Seismol. Soc. Am. 75, 455-473.

White, R.A., Harlow, D.H., 1993. Destructive upper-crustal earthquakes in Central America since 1990. Bull. Seismol. Soc. Am. 83, 1115-1142.

Williams, H., 1960. Volcanic history of the Guatemalan Highlands. University of California. Geol. Sci. 38, 86-90.

Williams, S.N., Self, S., 1983. The October 1902 Plinian eruption of Santa María volcano, Guatemala. J. Volcanol. Geotherm. Res. 16, 33-56.

Zablocki, C.J., 1976. Mapping thermal anomalies on an active volcano by the self-potential method, Kilauea, Hawaii. Proceedings, 2d UN Symposium of the development and use of geothermal resources, San Francisco, CA, May 1975, 2, pp. 1299-1309.

Zlotnicki, J., Nishida, Y., 2003. Review on morphological insights of self-potential anomalies on volcanoes. Surv. Geophys. 24, 291-338. doi:10.1023/B:GEOP.0000004188.67923.ac. 